\title{
Deciphering the Relevance of Bone ECM Signaling
}

\author{
Natividad Alcorta-Sevillano ${ }^{\dagger}$, Iratxe Macías ${ }^{\dagger}$, Arantza Infante *(i) and Clara I. Rodríguez *(i) \\ Stem Cells and Cell Therapy Laboratory, Biocruces Bizkaia Health Research Institute, Cruces University \\ Hospital, Plaza de Cruces S/N, Barakaldo, 48903 Bizkaia, Spain; \\ natividad.alcortasevillano@osakidetza.eus (N.A.-S.); iratxe.maciasgarcia@osakidetza.eus (I.M.) \\ * Correspondence: arantza.infantemartinez@osakidetza.eus (A.I.); cirodriguez@osakidetza.eus (C.I.R.) \\ † These authors contributed equally.
}

Received: 20 October 2020; Accepted: 7 December 2020; Published: 7 December 2020

\begin{abstract}
Bone mineral density, a bone matrix parameter frequently used to predict fracture risk, is not the only one to affect bone fragility. Other factors, including the extracellular matrix (ECM) composition and microarchitecture, are of paramount relevance in this process. The bone ECM is a noncellular three-dimensional structure secreted by cells into the extracellular space, which comprises inorganic and organic compounds. The main inorganic components of the ECM are calcium-deficient apatite and trace elements, while the organic ECM consists of collagen type I and noncollagenous proteins. Bone ECM dynamically interacts with osteoblasts and osteoclasts to regulate the formation of new bone during regeneration. Thus, the composition and structure of inorganic and organic bone matrix may directly affect bone quality. Moreover, proteins that compose ECM, beyond their structural role have other crucial biological functions, thanks to their ability to bind multiple interacting partners like other ECM proteins, growth factors, signal receptors and adhesion molecules. Thus, ECM proteins provide a complex network of biochemical and physiological signals. Herein, we summarize different ECM factors that are essential to bone strength besides, discussing how these parameters are altered in pathological conditions related with bone fragility.
\end{abstract}

Keywords: ECM; bone fragility; fracture risk; bone disease; ECM signaling

\section{Introduction}

The bone mineralized extracellular matrix (ECM) is predominantly responsible for bone's resistance to fracture, defined as bone strength. Bone formation or internal reconstruction will determine not only the spatial structure of the tissue but its mechanical properties. Bone mass has been used as a predictor of bone fragility; however, it is only a partial correspondent. Indeed, the skeleton derives its resistance to fracture from multiple components regulated across several levels of hierarchical organization. That way, the relative composition, organization, and maturity of the mineral and organic matrix have a paramount relevance on how bones respond to mechanical demand.

\subsection{Bone Extracellular Matrix Composition}

Bones involve living cells embedded in a mineralized matrix, consisting of organic and inorganic phase [1]. While the inorganic matrix is responsible for the ability to resist deformation (bone strength and stiffness), organic matrix allows energy absorption (toughness) [2]. The cellular component of bone is in constant interaction with the surrounding ECM, which affects cellular function by regulating different signaling pathways. All in all, different cells and molecules that compose bone matrix are involved in bone strength and, therefore, alterations in either fraction may affect bone composition and mechanical properties, determining fracture risk [3]. 


\subsubsection{Inorganic Matrix}

The inorganic (or mineral) fraction of bone tissue, composed of a combination of calcium and phosphorus salts, (predominantly in the form of hydroxyapatite $\left.\left(\mathrm{Ca}_{10}\left(\mathrm{PO}_{4}\right)_{6}(\mathrm{OH})_{2}\right)\right)$, is of ultimate importance to bone strength and stiffness. Crystals of calcium phosphate, produced by osteoblasts, are laid down in precise amounts within the fibrous matrix, leading to bone mineralization (also known as calcification). Mineral is initially deposited between the ends of collagen fibrils of the matrix, whilst during bone maturation hydroxyapatite crystals grow and aggregate [4].

When the maturation process occurs, expressed proteins regulate ordered deposition of mineral by regulating the amount and size of hydroxyapatite crystals formed. Two proteins appear essential in bone mineralization: type I collagen, which constitutes the scaffold upon which mineral is deposited, and alkaline phosphatase, that hydrolizes pyrophosphate (a strong inhibitor of mineralization) plus modifies the phosphorylation status of osteopontin (OPN), a factor implicated in bone remodeling [5]. Other bone matrix proteins are also known to regulate the mineralization process such as proteoglycans [6], matrix Gla-protein [7] and various phosphate-regulating proteins. Bone mineralization is also controlled by systemic hormones such as parathyroid hormone (PTH) and vitamin D [8]. PTH, the principal regulator of calcium homeostasis, enhances the release of calcium from the large reservoir contained in the bones [9] whilst, vitamin D stimulates the intestinal absorption of calcium and phosphorus to achieve enough calcium concentration [10]. Even more, the later also promotes differentiation of osteoblasts, stimulating the expression of bone crucial players; such as bone-specific alkaline phosphatase, osteocalcin $(\mathrm{OC})$ and osteonectin $(\mathrm{ON})$, among others.

Finally, the degree of mineralization, closely linked with bone strength [11], is mostly determined by the rate of bone turnover [12]. High bone turnover decreases the overall bone mineralization leading to lower bone stiffness. On the contrary, a reduced bone turnover leads to the accumulation of older and more extensively mineralized bone [12], with the consequent biomechanical drawbacks: it makes bone more brittle [13] and leads to the accumulation of damaged (aged) bone with reduced elastic properties, facilitating microcrack and fracture occurrence. Therefore, adequate balance between bone formation and resorption is crucial for bone quality [14].

\subsubsection{Organic Matrix}

Proteins that compose bone ECM can be divided into collagen and, to a minor extent, other noncollagenous proteins (NCPs). Bone-forming cells (osteoblasts) secrete the main compound of the organic matrix: type I collagen, which constitutes about $85-90 \%$ of the total bone protein content. Type I collagen, encoded by COL1A1 and COL1A2 genes, not only plays a major structural role in bone but also contributes to tissue organization and therefore to its mechanical properties [15]. Type I collagen is first synthesized as the precursor procollagen, being subsequently stabilized by post-translational modifications and disulfide bonds. Then, it is secreted into the ECM, cleaved of the $\mathrm{N}$ - and C-terminals, and processed until native triple helix collagen is obtained.

$\mathrm{NCPs}$, such as proteoglycans, SIBLING proteins (small integrin-binding ligand, $\mathrm{N}$-linked glycoproteins), glycosylated proteins, $\gamma$-carboxylated proteins, and other serum-derived proteins, are present in the bone matrix taking part in collagen assembly and crosslink formation [16] affecting the mechanical properties of collagen. This way, abnormalities in collagen crosslinks have been associated with increased fracture risk $[17,18]$.

All in all, the correct synthesis and fiber orientation of collagen are mandatory to obtain a healthy bone matrix able to withstand bone tensile strength. As such, it is not surprising that defects in type I collagen have dramatic effects on the skeleton.

\subsubsection{Cellular Components}

Bone is additionally composed of four different cell types that are in constant interaction with the surrounding ECM [19]. First, osteoprogenitor cells have the capacity to divide and differentiate 
into different bone cells. These cells, also known as mesenchymal stem cells (MSCs), differentiate to osteoblasts under osteogenic conditions. Osteoblasts are bone forming cells that synthesize and secrete the collagen matrix plus accomplish the mineralization of bone matrix. Then, when the secreted matrix surrounding the osteoblast calcifies, the osteoblast becomes trapped within it. As a result, it changes in morphology, becoming an osteocyte, the primary cell of mature bone that maintains the bone tissue. Finally, osteoclasts, multinucleated cells derived from hematopoietic progenitors, are the responsible for bone tissue degradation. Since bone is a dynamic tissue, bone remodeling is tightly regulated by both osteoblasts and osteoclasts: while osteoblasts form new bone, osteoclasts resorb it.

\subsection{Bone Structure: Microarchitecture}

Overall, the human skeleton is composed of bones grouped in four categories: long bones (femur, tibia, clavicles), short bones (for instance carpal and tarsal bones), flat bones (such as the ribs, mandible and skull) and irregular bones (such as vertebrae). All of them are composed of two types of bone tissue which can be distinguished macroscopically, differing in their architecture but similar in molecular composition: cortical (or compact) bone and trabecular (or cancellous) bone ( $80 \%$ and $20 \%$ of human skeleton, respectively) [20]. Although composed by the same components, mainly hydroxyapatite, collagen and water, trabecular bone is less mineralized (it has lower calcium content and higher water content), presenting lower tissue density and mineral content compared to cortical bone [21]. Consequently, cortical bone is densely packed, providing the strength and rigidity to bones. On the contrary, trabecular bone, responsible for the most bone turnover [22], is a porous material composed of a network of trabeculae organized to optimize load transfer, dispersing the energy of loading [23]. The cortical to trabecular ratio in each bone varies depending on the bone type and the specific skeletal site of that bone. Thus, cortical bone is mainly present in shafts of long bones and outer surfaces of flat bones, whereas trabecular bone is found at the end of long bones, vertebral bodies and the inner part of flat bones.

Alterations in bone ECM components can disrupt ECM-bone cell signaling leading to deterioration of bone mineral density (BMD) (the content of calcium in a certain volume of bone) and/or bone microarchitecture, (the organization of bone components in space), the two main parameters determining bone strength. In vivo quantification of cortical and trabecular BMD, geometry and microarchitecture can be analyzed at the same time by quantitative computed tomography methods, rendering the amount of cortical and trabecular bone tissue and features of trabecular (trabecular number, trabecular thickness, trabecular separation) and cortical (cortical thickness and porosity) bone microarchitecture.

\subsection{Biophysical Properties of Bone Extracellular Matrix}

A growing body of evidence in ECM biology points at biophysical properties of the bone ECM (mineral crystal size, their crystallinity (the degree of structural order) and the degree and type of collagen crosslinking,) as important determinants of cell behavior. Indeed, every cell in its anatomical localization has to balance the external forces dictated by the mechanical properties of its environment, which results from the compression exerted by neighboring cells as well as the stiffness of the surrounding ECM.

Regarding the biophysical properties of the mineralized matrix that surrounds bone cells, not only does the degree of mineralization matter so does the individual characteristics of the hydroxyapatite crystals (their size and shape) and crystallinity. Indeed, excessive crystal growth damages collagen fibers, affecting the tissue mechanical properties. Moreover, bone strength seems to be favored by greater mineral crystal size heterogeneity [24].

The biophysical properties of collagen type I fibers affect cellular behaviors [25], since cells respond differently to denatured collagen than to mature, crosslinked collagen fibrils [26]. Collagen crosslinking is a major post-translational modification which determines biophysical properties such as tensile strength and viscoelasticity [17]. Crosslinks can be divided into enzymatic and nonenzymatic. 
Enzymatic crosslinking is a process in which the ends of the collagen molecules are linked (so their number is greatly limited), acquiring a more stable, trivalent, nonreducible conformation [27]. When mature crosslinks accumulate, collagen fibril remodeling is inhibited and stiffness of the fibril increased, providing strength to the tissue [28]. That way, enzymatic crosslinking bears beneficial effect on the mechanical properties of collagen [17]. Conversely, nonenzymatic crosslinking does not involve any enzymes, and are found at any position along the collagen molecule to connect either collagen molecules or fibrils. Nonenzymatic glycation results in the formation of intermediate products (advanced glycation end-products (AGEs)) that undergo additional reactions to create crosslinks that form within and across collagen fibers. Thus, nonenzymatic crosslinking results in a brittle collagen network that, when accumulated or when its spatial distribution is altered leads to deteriorated bone mechanical properties $[29,30]$. In summary, while enzymatic crosslinking of collagen is generally considered to have a positive effect on bone's mechanical properties, nonenzymatic crosslinking can lead to deteriorated bone mechanical properties.

\subsection{Bone Extracellular Matrix Signaling}

As previously mentioned, the majority of bone ECM is composed by collagen type I, reaching up to $90 \%$ of the protein content. However, proteomic analysis of decalcified bone has identified the minority presence of more than $100 \mathrm{ECM}$ proteins in bone, different from collagen, reflecting the complexity of bone ECM [31,32].

In addition to structural role and thanks to their ability to bind multiple interacting partners like other ECM proteins, growth factors, signal receptors and adhesion molecules [33], the diverse set of ECM proteins also reveal other crucial biological functions. ECM components thus, provide a complex network of biochemical and physiological signals that contribute to bone metabolism, affecting fundamental cellular processes (such as proliferation, differentiation, migration and survival) via the integration of a number of signals that constitute the matrix-to-cell signaling [33]. This way, ECM regulates both, the osteoblast-lineage (for instance progenitors, mature osteoblasts, and osteocytes) and osteoclast-lineage (including precursors and mature osteoclasts), including also the crosstalk between them [34]. Besides, external influences can exert changes in these complex signaling systems as for instance vitamins [35] hormones [36,37] and/or minerals [38] intake.

In this section, we will highlight the main pathways that are involved in bone ECM signaling to offer a better understanding of how cell-matrix signaling occurs and the relevance of thereof in pivotal biological processes.

\subsubsection{Integrin-Dependent Cell Adhesion Structures in Cell-ECM Signaling}

Cell migration, essential for embryonic development, tissue renewal and immune response among other key processes, becomes crucial for correct bone remodeling. The formation of new bone needs the migration and differentiation of MSCs, an event tightly controlled by sequential activation of diverse transcription factors which regulates the expression of specific genes responsible for this transition [39]. The activation of these signaling cascades, and thus cell fate, is governed by the integration of all the signals that the cell receives from its environment through the ECM and intercellular adhesions.

Integrin-dependent cell adhesion structures allow cells to be attached to the ECM, binding intracellular actin fibers to extracellular proteins like fibronectin. This connection also transmits the mechanical force and regulatory signals between the ECM and the cytoskeleton of the cells.

Integrins are heterodimeric transmembrane receptors formed by one $\alpha$ and one $\beta$ subunit. There are several subunit isoforms (eighteen $\alpha$ and eight $\beta$ ) that can be noncovalently assembled into 24 combinations [33] and the exact subunit combination dictates their binding specificity to different ECM components. Within the cell, the intracellular domain do not bind directly to the cytoskeleton, they do so via adapter proteins such as talin, $\alpha$-actinin, filamin, vinculin and tensin $[40,41]$, which transmit the applied forces on ECM to the actin cytoskeleton. Conversely, forces applied to actin, the so-called 'traction forces', are also transmitted to the ECM through the same mechanism [42]. 
As mentioned, integrins can be assembled into several combinations that are different in their mechanosensitivity and elicited cellular responses. Mechanosensation depends on ECM material properties, being broadly demonstrated that ECM stiffness determines cellular response during MSC differentiation into osteoblasts [43-45]. Furthermore, the communication also works the other way around; cellular response alter ECM's mechanical stiffness as well [46].

\subsubsection{MMPs as Signal Regulators}

The main function of matrix metalloproteinases (MMPs), a family of zinc-dependent enzymes, is to degrade the proteins of the ECM, cleaving structural components such as collagen and gelatin.

MMPs expression and activity are regulated at multiple levels; inactive proenzyme transcription, translation and secretion, as well as proenzyme activation or inactivation via signaling of different factors like cytokines, growth factors or even ECM proteins. Normally, secreted MMPs are synthesized as proenzymes which are activated by proteolytic cleavage of the $\mathrm{N}$-terminal prodomain by serine proteases or by active MMPs. Classic activators of MMPs include the activator protein-1, nuclear factor kappa $B$, tumor necrosis factor- $\alpha$, and the transforming growth factor beta (TGF- $\beta$ ) together with some interleukins. There is growing evidence showing the importance of balance amongst MMPs and their inhibitors, tissue inhibitors of metalloproteinases (TIMPs) and the membrane anchored gly coprotein RECK, for MSC fate and stage-specific expression during bone cells differentiation [47].

MSCs from different organs have shown differential expression and secretion of MMPs/TIMPs [48,49]. In fact, the treatment of these cells with a broad spectrum of MMP inhibitors leads to alterations in migration, proliferation, and osteoblastic differentiation, supporting that these processes are MMP dependent $[48,50]$. Mauney J. and Volloch V. showed that bone marrow MSCs undergoing adipogenic differentiation, express more MMPs than TIMPs [51]. However, under osteogenic differentiation conditions, cells express more TIMPs than MMPs, reinforcing the key role of MMP/TIMP balance for matrix modulation and MSC differentiation [52].

MMPs, apart from ECM degrading enzymes, have a central role regulating several signaling pathways by cleaving many circulating, cell surface and pericellular proteins irreversibly. Among the molecules that are released by MMPs, TGF- $\beta$ stands out, responsible of MSCs migration to resorbed sites promoting bone formation [53]. MMP-mediated activation and release of TGF- $\beta$ has been described as a negative feedback mechanism to limit MMP expression and further TGF- $\beta$ release [54]. Osteoclast secretion of MMP-9 activates trapped TGF- $\beta$ in the ECM, and this TGF- $\beta$ may downregulate cathepsin K and MMP-9 expression; thereby controlling the amount of bone resorption that occurs by mature osteoclasts [52]. However, TGF- $\beta$ can also lead to an increase in MMP-13 expression, which is related with increased osteoclast differentiation and activation [55,56]. Altogether, this evidence underlines the required tight regulation and interconnection between TGF- $\beta$ and MMPs pathways to achieve a correct bone homeostasis.

\subsubsection{TGF- $\beta$ Signaling Pathway}

As stated previously, TGF- $\beta$ pathway plays a crucial role in bone metabolism regulating bone mass and quality [57]. There are more than 40 members in the TGF superfamily, including bone morphogenetic proteins (BMPs), growth and differentiation factors, activins, nodal, and Müllerian inhibitory substance [58], in addition to TGF- $\beta 1$, TGF- $\beta 2$ and TGF- $\beta 3$ isoforms, being TGF- $\beta 1$ one of the most abundant cytokines in the bone matrix [59].

In bone, TGF- $\beta$ is produced as large precursor molecule by bone-forming osteoblasts, being composed of mature TGF- $\beta$ and latency-associated protein (LAP). TGF- $\beta$ remains sequestered in the ECM as an inactive, latent form since LAP remains noncovalently bound to mature TGF- $\beta$ as it is secreted. However, upon osteoclastic resorption, LAP is cleaved, releasing the active TGF- $\beta$. A gradient of active TGF- $\beta$ promotes the recruitment of MSCs to the recently resorbed bone surface by inducing chemotaxis and proliferation [60]. Once MSCs reach these sites, they differentiate into 
osteoblasts in response to environmental factors (such as bone-matrix-derived insulin-like growth factor 1) [61].

In addition to regulating the proliferation and differentiation of MSCs, active TGF- $\beta$ has shown to be also an important regulator for osteoclastogenesis in a dose-dependent manner. High concentrations of active TGF- $\beta$ generated at resorption areas inhibit the recruitment of osteoclast precursors, protecting it from further resorption during bone formation process [62]. Instead, low concentrations of active TGF- $\beta$ induce the migration of osteoclast precursors [63]. This dual effect of TGF- $\beta$ is also important in osteoclast differentiation. Low TGF- $\beta$ levels stimulate osteoclast differentiation, whereas high levels inhibit such differentiation by regulating receptor activator of nuclear factor $k \beta$ ligand (RANKL)/osteoprotegerin (OPG) ratio [64]. In normal conditions, osteoblasts and osteocytes secrete RANKL, which binds to its receptor in osteoclasts (RANK) and promotes their differentiation. However, TGF- $\beta$ can induce the expression of OPG in osteoblasts, a cytokine that acts as a decoy receptor for RANKL [65], thus inhibiting osteoclasts differentiation.

More recently, it has been shown that TGF- $\beta$ presents both inhibitory and stimulatory effects in human osteoclast differentiation via Smad1 and Smad3 signaling, respectively [66]. These facts points out the complexity of TGF- $\beta$ signaling governing the regulation of a wide range of bone metabolisms cellular functions.

Other pivotal members of TGF superfamily are BMPs. BMPs induce MSCs differentiation into bone $[67,68]$ via the interaction with their cell surface receptors (BMPRs) in a canonical pathway similarly to TGF- $\beta$, leading to the activation of Smads. Like TGF- $\beta$, BMPs also activate several non-Smad signaling transducers, namely, mitogen-activated protein kinase (MAPK) pathways, including extracellular signal-regulated kinases (ERKs), c-Jun amino terminal kinase (JNK), p38 MAPK, the IKB kinase, phosphatidylinositol-3 kinase and Akt, as well as Ras homolog family GTPases.

Several studies have demonstrated that following TGF- $\beta$ /BMP induction, both the Smad and p38 MAPK pathways converge at the runt-related transcription factor 2 (Runx2) gene to control mesenchymal precursor cell differentiation [69,70]. Runx2 promotes the differentiation of progenitor cells into osteoblast, preventing adipogenesis [71] and exhibiting its essential role in MSC fate determination.

\subsubsection{Wnt Signaling Pathway}

Wingless-type mouse mammary tumor virus integration site family (Wnt) is essential for skeletal formation and development, being involved in a variety of processes like differentiation, proliferation and synthesis of bone matrix by osteoblasts as well as osteoclasts differentiation and function [72,73]. In fact, alterations not only in the intensity, but amplitude, and duration of Wnt signaling pathways affects skeletal formation during development, in addition to bone remodeling, regeneration, and repair during the lifespan [74].

Wnts can trigger several signaling cascades, among them, the most studied is the canonical Wnt/B-catenin pathway. Briefly, Wnt elicits the stabilization and nuclear translocation of $\beta$-catenin, which is a transcription coregulator. In the absence of Wnt, $\beta$-catenin is phosphorylated by a large protein complex (adenomatous polyposis coli/Axin/glycogen synthase kinase - $3 \beta$-complex), leading to its ubiquitination and proteasomal degradation through the $\beta-\mathrm{TrCP} / \mathrm{Skp}$ pathway. However, when Wnt is secreted, it binds to membrane Frizzled receptors and triggers a cascade of several intracellular events, allowing $\beta$-catenin translocation to the nucleus, activating Wnt target genes expression [75].

Canonical Wnt signaling pathway promotes MSCs differentiation into osteoblasts by preventing apoptosis in both; osteoblast progenitor cells and differentiated osteoblast [76]. As expected, Wnt signaling is also involved in cellular lineage dichotomy; more precisely Wnt10a, Wnt10b and Wnt6 favor osteogenesis at the expense of adipogenesis; suppressing the differentiation of MSCs to adipocytes while facilitating their differentiation to osteoblasts through the canonical Wnt pathway $[77,78]$.

As stated throughout the present review, osteoclast progenitor differentiation is tightly regulated by osteoblasts and osteocytes. In normal conditions, osteoblasts and osteocytes express RANKL, which binds to osteoclasts receptor RANK, promoting their differentiation. However, the canonical 
activation of Wnt signaling pathway in osteoblast-lineage cells enhances the expression of OPG, a decoy receptor of RANKL, suppressing osteoclast differentiation and thus bone resorption [79].

\section{Bone ECM Alteration in Pathological Conditions Associated with Fragility}

There are numerous diseases related to bone fragility in which ECM is altered preventing to perform its normal functions. Herein we'll focus mainly on two bone disorders; the prevalent illness osteoporosis and the rare disease OI, both characterized by low bone mass.

\subsection{Bone Extracellular Matrix Composition}

\subsubsection{Bone Extracellular Matrix Composition in Osteoporosis}

Osteoporosis is a worldwide disease characterized by reduction of bone mass and alteration of bone architecture [80]. According to the National Institutes of Health Consensus Development Panel on osteoporosis [81], it is defined as "a skeletal disorder characterized by compromised bone strength leading to an increased risk of fracture." Osteoporosis mainly occurs in postmenopausal women [82] and elderly men [83], affecting approximately 200 million people [84-86], even more, its prevalence is expected to increase significantly in the future because of aging of the population, especially in developed nations [87]. Worldwide, approximately 8.9 million fractures are caused by osteoporotic fracture annually: over $50 \%$ of postmenopausal white women and $20 \%$ of white men will have an osteoporotic-related fracture in their lifetime [88]. Besides the health and social challenges, osteoporosis represents a major concern of the health care systems because of its growing economic burden.

The hazardous increase in the risk of fractures is a major cause of concern for the affected population [3]. Although BMD measurement is one of the most widespread diagnostic tools, the majority of fragility fractures occur in individuals whose BMD value is above the diagnostic threshold of osteoporosis [89], stressing the notion that BMD is just one among several indicators of bone health. Clearly, there is a need for improvement in the identification of patients at risk for fracture. To this extent, assessment of fracture risk should also rely on other bone properties related with bone quality [90], such as the composition of bone tissue (proportion of hydroxyapatite, water, type I collagen, and other $\mathrm{NCPs}$ ), the biophysical properties of these components (the degree and type of collagen crosslinking, the mineral crystal size and their crystallinity), the ECM structure and the altered signaling pathways. Hence, each one of these properties may independently contribute to the increased or decreased risk of fracture, even without meaningful changes in BMD.

As an example of inorganic matrix bone composition of implication, it has been shown that the degree of trabecular bone matrix mineralization is slightly reduced in premenopausal women with idiopathic osteoporosis (osteoporosis of under 50 years adults with unknown cause) compared to normal controls [91]. Concerning organic matrix, COL1A1 gene is implicated in reduced BMD in osteoporosis; in fact, type I collagen polymorphisms (Sp1 [92] and $+1245 \mathrm{G} / \mathrm{T}$ [93]) play a role in development of osteoporosis and fracture. Thus, osteoporosis may alter the collagen alignment and mineral geometry in bone formed before and after the onset of this disease [94].

NCPs regulate the matrix assembly and play a significant role in the structural organization of bone, thus influencing its mechanical properties [95]. NCPs levels vary during aging and disease such as osteoporosis, leading to an increased fracture risk. That way, alteration in NCPs such OPN, OC and ON could increase the risk of developing osteoporosis [96]. The role of OPN in bone remodeling has been confirmed by studies on osteoporosis development in which ovariectomized (OVX) OPN ${ }^{+/+}$mice lost bone mass, while OVX OPN ${ }^{-/-}$mice showed higher bone volume than the earlier. Furthermore, when OVX mice were treated with anti-OPN antibody, a marked inhibition in bone loss was observed, along with a reduction in the number of resorptive areas [97]. These animal studies are in agreement with observed in affected patients, in which higher levels of serum OPN were found in postmenopausal women with osteoporosis, compared to nonaffected ones [98,99]. 
OC is considered a marker of bone formation, therefore several epidemiological studies tried to establish the role of serum and urinary OC detection as an accurate biomarker for osteoporosis. However, the results are at least controversial. In spite some studies have reported that osteoporotic women have increased serum OC [100-102], recently data revealed no significant difference in serum OC level between postmenopausal osteoporosis cases and controls [39]. This could be explained by OC molecules are quite heterogeneous in the circulation and can be influenced by glucose metabolism.

The third NCPs that is considered, ON has an important role in matrix regulation and mineralization, making ON a good candidate for the osteoporosis onset [103]. In fact, ON-null mice have decreased bone formation in addition to decreased osteoblast and osteoclast surface (the proportion of the bone covered with osteoblasts or osteoclasts) and number, leading to decreased bone remodeling with a negative bone balance, causing profound osteopenia [104]. Moreover, ON polymorphisms seem to affect BMD in humans. Delany and coworkers observed that the haplotype commonly associated to a high bone density is mainly expressed in normal subjects than in osteoporosis patients, while the expression of ON haplotype associated to low BMD is higher in osteoporosis patients than in controls [105].

Finally, both collagen [106] and NCPs undergo different post-translational modifications, which alter the quality of the ECM and the response of bone to mechanical load. Hence, bone matrix protein phosphorylation levels are tightly related with bone fracture risk. To address this gap, a recent study has demonstrated that as people age, the total phosphorylation level declines by approximately $20 \%$ for bone matrix proteins [107]. Moreover, these outcomes suggest that the decline of total protein phosphorylation of ECM contributes to bone fragility and could lead to development of osteoporosis.

\subsubsection{Bone Extracellular Matrix Composition in Osteogenesis Imperfecta}

Osteogenesis imperfecta (OI), also called "brittle bone disease", is a rare genetic disorder characterized by an increased susceptibility to bone fractures and decreased bone density [88]. In the majority of cases, it is caused by mutations in the COL1A1 or COL1A2 genes and, as expected, associated to abnormality in the synthesis and/or processing of type I collagen. Nowadays, mutations in up to 19 different genes have been identified in a dominant and recessive traits [108,109]. Besides the genetic heterogeneity, OI presents a wide clinical variability [110] in where clinical manifestations range from mild, with a nearly asymptomatic form, to most severe one resulting in perinatal mortality [111]. Genetic mutations that cause a quantitative reduction of type I collagen cause milder forms of OI disease, and conversely, structural mutations of type I collagen, significantly affect the quality of the bone matrix resulting in moderate to lethal forms of OI.

Since type I collagen is the major component of bone being essential for bone mineralization, it can be assumed that changes in collagen quantity or quality will have detrimental effects on mineralization. In line with this observation, several studies have claimed that OI patients have higher average mineralization densities than age-matched healthy controls [112,113], and increased BMD distribution [114]. It has been suggested that the higher mineralization is a consequence of abnormal OI ECM assembly, which results in increased water fraction that is available for mineral deposition. Thus, although mineralization in OI patients is increased, bones are brittle due to an alteration in bone ECM formation and structure.

Moreover, there are OI patients presenting mutations in specific genes that directly affect the bone mineralization process such as IFITM5 (Interferon induced Transmembrane Protein 5) [115] and SERPINF1 (Serpin Family F Member 1) [116]. Histological studies on iliac crest biopsy specimens from these OI patients described lamellae with irregular organization and a meshlike appearance $[117,118]$. Although the defective proteins that encode the genes mentioned are not involved in the synthesis of type I collagen there is evidence for reduced type I collagen production and increased mineralization in primary osteoblast cultures [119], even hypermineralization of bone tissue [120].

Regarding the organic matrix, OI patients present a reduced quantity of bioactive type I collagen due to alterations in multiple processes that contribute to its synthesis, secretion, processing, assembly and 
interaction with other matrix components, as mentioned previously [121]. As type I collagen is the most abundant protein in bone ECM, its normal level reduction will affect ECM composition and in consequence, ECM functions.

On the other hand, several alterations in NCP levels have been reported in OI patients [122,123]. First, bone sialoprotein, OC [124] and alpha 2-HS glycoprotein concentrations were found increased in cortical bone from OI patients [125]. OI cell matrices present not only a reduced level of proteins such as collagen, but also a decrease in decorin [126] and ON [127]. Moreover, mutations in SPARC (the gene encoding ON) have been identified in individuals with recessive OI [128], which demonstrated severe bone fragility, pointing out that the collagen-binding function of $\mathrm{ON}$ plays a critical role in collagen deposition in bone [129].

Osteoblasts from OI cultures exhibit reduced amounts of insoluble collagen deposition and increased synthesis of the glycosaminoglycan hyaluronan when compared to ECM deposited by osteoblasts from control individuals [130]. Defects in collagen secretion or deposition that might contribute to the fragility of the OI bone by interfering with complete mineralization and/or normal tissue architecture [129].

All in all, OI affects the ECM in multiple ways [121] and the study of OI has clearly highlighted the essential role of material properties in bone strength [131].

\subsection{Bone Extracellular Matrix Structure}

\subsubsection{Bone Morphology in Osteoporosis}

Osteoporosis animal models and human patients share not only bone mass reduction but alteration of bone architecture. Cortical bone of the mid-diaphysis in OVX mice (murine model of postmenopausal osteoporosis), show a reduced tissue mineral density and increased cortical porosity, this later feature also exhibited by OVX rat model of postmenopausal osteoporosis rat (Sprague-Dawley). An increase in cortical vascular porosity may diminish bone strength as well as alter bone mechanotransduction via interstitial fluid flow, both of which could contribute to bone fragility during postmenopausal osteoporosis [132]. These results are in agreement with osteoporosis patients outcomes in which the cortical bone becomes more and more porous with increasing age, and therefore, the largest loss of absolute bone mass is in cortical bone [29]. Since cortical bone plays a major role in determining the mechanical competence of bone and the risk of fracture, the age related alterations of its geometrical features and its local porosity may alter bone strength and lead to bone brittleness.

Trabecular bone has been also shown to be affected in osteoporosis. The number of trabeculae, the trabecular thickness and the degree of connectivity influence the mechanical strength of a bone. Thus, in OVX mice (murine model of osteoporosis), the trabecular bone volume of the distal-metaphysis is decreased [133]. Moreover, in male Wistar rats subjected to orchiectomy bone loss is observed too. Separately, the orchiectomy led to significant tomographic alterations in the trabecular bone number, trabecular separation, and trabecular pattern factor [134]. The same results have been reported in early osteoporosis patients, since the bone loss is mainly a trabecular deficiency, and a decrease of all these characteristics is observed [29]. Bones with increased risk for osteoporotic fractures, present remaining trabecular tissue largely heterogeneous [135], with regions of different mineralization, stiffness and strength. For example, it was demonstrated that bone structure deterioration of the tibial plateau due to osteoporosis was region-specific [136], and the greatest decrease in bone volume fraction was found in the medio-medial segments and the lowest bone volume was found in central segments (tibial spine). It has been proposed that these changes are a transient and site-specific characteristic of osteoporosis, whereby the trabecular tissue properties are altered varyingly as the disease progresses. In addition, changes in the distribution of mechanical stimuli related to changes in the microarchitecture of the trabecular have been studied [137]. Variations in the morphology of the trabecular bone have been predicted, such as an increase of $30 \%$ in porosity, which significantly altered the distribution of mechanical stimuli of the environment where the cells are located. These results suggests that changes 
in the microarchitecture cause a proportional decrease in the mechanical stimuli that may drastically affect the mechanoregulation of bone regeneration, promote microcracks and accelerate osteoporosis.

\subsubsection{Bone Morphology in Osteogenesis Imperfecta}

Bone morphology has also been studied in patients suffering from OI [138], presenting BMD, trabecular volumetric BMD, total bone area, and cortical bone area lower in OI than in healthy age- and gender-matched controls [139]. Higher tissue mineral density was found for OI bone, a dramatically rise in cortical porosity, canal diameter, and connectivity [140] along with a lower elasticity [141]. That way, compared to control group, the cortical thickness seems to be thinner in OI patients [142].

With respect to trabecular microstructure in patients with OI, significantly lower trabecular parameters including bone volume fraction (BV/TV) and bone trabecular number (Tb.N) [142], as well as increased trabecular spacing were observed in comparison to the control group. A tendency toward thicker trabeculae was found [139]. These observed results are possibly due to increased bone turnover that in turn increases trabecular perforations and thus leads to preferential loss of thin trabeculae [143]. Taking everything into account, the mutation-induced collagen defects alter the collagen matrix, thereby affecting the mineralization and leading to increased brittleness.

\subsection{Bone Extracellular Matrix Biophysical Properties}

\subsubsection{Bone Extracellular Matrix Biophysical Properties in Osteoporosis}

Though osteoporosis is generally defined as a loss of bone mass, there are considerable matrix changes, particularly in collagen crosslinks, which cause a loss of bone quality $[3,18]$. Enzymatic crosslinks have been shown to be reduced in osteoporotic patients with hip fractures compared to healthy controls $[144,145]$. Moreover, collagen from the femoral head of osteoporotic women has a higher degree of hydroxylated lysine residues (formed from nonenzymatic crosslinks) than that from nonosteoporotic women [146].

Intermediate product generated from the nonenzymatic crosslink named AGEs accumulate with age and disease [17], so it is not unexpected that osteoporotic bone presents significantly more AGEs than normal healthy bone $[144,147,148]$. The activation of the RAGE (AGE receptor) inhibits osteoblast proliferation and differentiation [149], reduces matrix production [150], reduces bone formation [151] and increases osteoblast apoptosis [152], finally deteriorating bone's mechanical properties. All things considered, crosslinking properties of the matrix may alter the tissue properties and therefore play an important role in the decreased bone formation found in osteoporosis [153].

How menopause affects bone quality has been and is an intense research line, given the tight link between menopause and the development of osteoporosis. Thus, an analysis of bone matrix quality from healthy women with and without menopause pointed out that women with menopause demonstrate a decrease in mineral/organic ratio, microhardness, mineral maturity and crystallinity, suggesting the alteration of local mineral content and microhardness [154], in spite that the mean degree of mineralization was no different. Outcomes that are in line with previous study, in which microhardness was significantly lower in osteoporotic patients compared with controls [155].

\subsubsection{Bone Extracellular Matrix Biophysical Properties in Osteogenesis Imperfecta}

When the secreted collagen type I has altered post-translational modification, leading to defective crosslinking [156], the collagen reduces its ability to correctly bind to other matrix molecules. Mutations in genes that are involved in collagen crosslinking have been reported in OI patients [157], such as SERPINH1, FKBP10 and PLOD2 [123].

SERPINH1 encodes heat shock protein 47 (Hsp47), a collagen-specific molecular chaperone. Hsp47 transiently associates with triple-helical procollagens in the endoplasmic reticulum (ER) and dissociates at the cis-Golgi, returning to the ER via its ER retention signal [158]. Mutations in Hsp47 and consequent impairment of the chaperone function in the ER, lead to overhydroxylation and partial 
intracellular retention of procollagen I. Both consequences, ER stress and aberrant bone collagen crosslinking, underlie the OI pathology associated to crosslinking defects, but further studies are required [159].

Bruck syndrome is a disorder characterized by joint flexion contractures and skeletal dysplasia that shows strong clinical overlap with OI but is caused by biallelic mutations in either the FKBP10 or the PLOD2 genes [160-162]. PLOD2 encodes lysyl hydroxylase 2 (LH2), the enzyme responsible for hydroxylation of collagen telopeptide lysine. Telopeptide hydroxylysines are essential for the hydroxyallysine pathway of crosslinking, which produces mature crosslinks in extracellular collagen fibrils, crucial for the normal material properties of bone [163]. FKPB10 encodes FKBP65, an ER resident peptidylprolyl isomerase that functions as a molecular chaperone that aids in the folding of type I procollagen [164]. Moreover, it is involved in collagen crosslinking by specifically mediating the dimerization of LH2, which is required for its activity $[158,165]$. Type I collagen isolated from FKBP10 knockout mice revealed less stable crosslinks [166]. In the absence of FKBP10, collagen fibrils deposited in matrix are sparse and disorganized, consistent with the defect in crosslinking [167]. Thus, collagen monomers not able to crosslink may simply dissociate from fibers due to a low collagen concentration in media, leading to bone fragility and deformity. Overall, mutations in genes related with collagen processing and consequent impaired collagen crosslinking, lead to bone fragility, as can observe in some bone brittle patients.

In order to delve into the understanding of the high bone matrix mineralization observed in patients with OI, mineral composition (mineral particles size, alignment and mineral-to-matrix ratio) were analyzed. Studies in the oim murine model (OI mouse) demonstrated that the hydroxyapatite crystals are thinner and less-well aligned along collagen fibrils compared to controls [168]. That way, oim bones have lower stiffness that may result from the poorly organized mineral matrix with significantly smaller, highly packed and disoriented apatite crystals [169]. The same results were reported in OI patients: the size of mineral particles was the same or smaller than controls [170], but their packing density was increased [171]. Moreover, Raman spectroscopy showed that the mineral-to-matrix ratio was higher in OI samples, while the crystallinity was lower [141], suggesting that the mineral crystals were smaller but more abundant in the case of OI. These changes in crystal size, distribution and composition contribute to the observed decrease in mechanical strength and consequent bone fragility.

To sum up, studies on OI bones have shown increased bone mineralization, accompanied by hydroxyapatite crystals that are reduced in size, more densely packed and less-well organized along collagen fibrils. These features lead to changes in intrinsic bone material properties with the consequent increase in bone brittleness [131].

The following table summarized the different ECM alteration at matrix composition, microarchitecture and biophysical properties level in osteoporosis and OI (Table 1).

\subsection{Altered Bone Extracellular Matrix Signaling in Bone Pathologies}

\subsubsection{Integrins}

The integrity of collagen type I molecule has revealed to be essential for a correct binding to integrin cell receptors. Not all subunits that form integrins are equally affected in osteoporotic patients, for instance, $\alpha 2$ integrin, which is part of $\alpha 2 \beta 1$ heterodimer, is downregulated, in osteoporotic patients [172].

Another central aspect for this molecular interaction is the collagen triple helical conformation. This structure requires a glycine as every third residue to stabilize it, generating the characteristic (Gly-Xaa-Yaa) $n$ sequence [173]. The glycine at that position is essential, since even a single Gly substitution by another residue leads to OI phenotype [174]. Hamaia and colleagues, elucidated the precise (Gly-Xaa-Yaa) $n$ amino acid sequence in collagen required for integrin binding [175]. An interesting study focused on $\alpha 2 \beta 1$ integrin and how Gly mutations affect their integrin-collagen 
binding [174], pointed out that mutations occurring in crucial regions of collagen binding motifs avoid integrin interaction and, consequently, cell adhesion, leading to severe or lethal OI phenotypes.

Table 1. Alterations in extracellular matrix (ECM) composition, structure and biophysical properties in osteoporosis and osteogenesis imperfecta (OI).

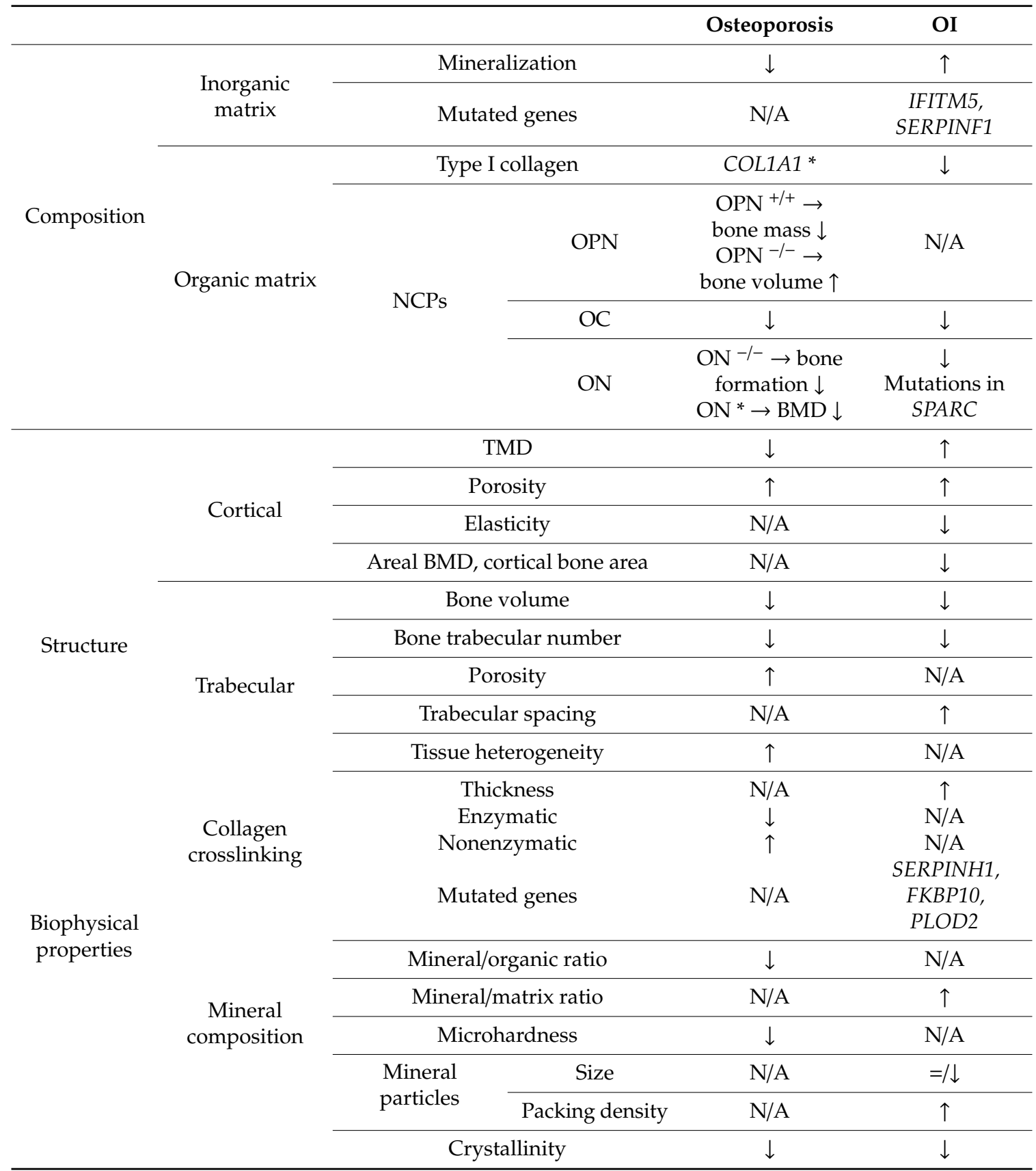

* Polymorphisms; $\downarrow$ decrease; $\uparrow$ increase; ${ }^{+/+}$wild type; ${ }^{-/-}$knockout, $=/ \downarrow$ similar or decrease; N/A, not available; for definitions of other abbreviations, please see the main text.

\subsubsection{MMPs}

Osteoclast activity is associated with an increase in MMP-9 expression which stimulates osteoclasts resorption and degrades ECM matrix proteins like collagen type I [176]. MMP-9 serum levels have been found to be overexpressed in osteoporotic bones [177]. In addition, high levels of MMP-2, as well as fragments derived from bone collagen by the cleavage of MMP-2, have been found in the circulation of osteoporotic patients [178]. Thus, in osteoporosis patients, the excessive MMPs activity and therefore 
osteoclasts activity is targeted by bisphosphonates, which reduce bone resorption by inhibiting the enzymatic activity of MMPs in osteoclasts. Some examples are the bisphosphonates based on highly selective MMP-2 inhibitors [179,180] and a TIMP-2-based MMP-14 inhibitor [181].

On the other hand, BMP1 is a metalloproteinase known to have procollagen C-proteinase activity that cleaves the C-propeptides from procollagens I-III [182]. Mutations of the BMP1 gene lead to defects in collagen processing and are associated with OI in humans [183-185] and other animal species such as mouse and zebrafish $[183,186,187]$, emphasizing the importance of all proteins involved in collagen processing to achieve a correct bone formation. Studies of mesenchymal stem cells have demonstrated that the collagen-binding $\alpha 2 \beta 1$ and $\alpha 11 \beta 1$ integrins both have an impact on osteogenic differentiation [172].

\subsubsection{TGF- $\beta$}

The existence of a fine-tuned bone ECM signaling to maintain bone microstructure becomes unquestionable given the existence of a number of bone pathologies with alterations in key signaling pathways, as an underlying pathological mechanism. Of relevance is the case of the TGF- $\beta$ signaling pathway, previously remarked, which is modulated by bone ECM proteins. A number of mutations have been identified in different members of the signaling pathway, leading to an array of rare genetic diseases, all of them sharing skeletal alterations such as compromised trabecular and cortical bone microarchitecture (Figure 1).

Marfan syndrome (MFS), a connective tissue disorder with a wide range of musculoskeletal and cardiovascular alterations, is caused mainly by mutations in FBN1 gene, which codes for Fibrillin-1, an ECM structural protein which polymerizes into microfibrils. Fibrillin-1, which in bone tissue represents less than $3 \%$ of ECM proteins, binds to latent TFG- $\beta$-binding proteins forming large latent TGF- $\beta$ complexes. Mutations in FBN1 gene lead to an increased pool of active TGF- $\beta$ and therefore to an enhanced TGF- $\beta$ signaling, featuring lower bone mass exhibited by affected individuals $[188,189]$. However, a high clinical variability is observed in MFS patients, and, in fact, more than 1800 different mutations in FBN1 (only 12\% recurrent) have been described [190]. Recently, alterations in microarchitectural parameters have also been described in long bones from MFS adults: trabecular bone shows reduced trabecular number and thickness as well as higher trabecular separation, whereas cortical bone shows reduced thickness and increased porosity [191]. It is still unclear whether there is an increased risk of fractures in MFS patients, recent studies point to an increased fracture risk in both pediatric and adult MFS patients $[172,192,193]$. The increased fracture rate was not found in pediatric patients with the lower mineral density, suggesting that an altered bone microarchitecture could be playing a pivotal role in MFS fracture risk [192]. On the contrary, a recent study, found that, in spite of the bone microarchitecture alterations, the estimated bone strength in MFS was similar to that expected for healthy controls. This in silico prediction could be explained by the fact that MFS bones exhibit an increased longitudinal growth, which could be counteracting the consequences of having deficiencies in bone mass and microarchitecture [191].

Loeys-Dietz syndrome (LDS) is caused mainly by mutations in genes coding for TGF- $\beta$ receptors, $T G F-\beta R 1$ and TGF- $\beta R 2$. Mutations are predicted and/or in vitro verified to inhibit the kinase activity of TGF- $\beta$ receptors and therefore diminish the activation of the pathway, but paradoxically aortic tissues of LDS patients show elevated TGF- $\beta$ signaling [194]. In fact, patients show clinical features that overlap with those shown by MFS patients, suggesting a common pathogenic mechanism, although in this case, patients show more aggressive vascular disease. As regards skeletal tissue, patients show thinner cortical bones, low BMD and increased risk of fractures [195,196] but, up to now, there are no studies addressing bone microarchitecture in these patients. Mouse models carrying mutations in TGF- $\beta R 2$ recapitulate the low bone mass phenotype of LDS patients, resembling severe human LDS [197]. Cortical bone at the femoral shaft of mice proved to be especially affected, with decreased bone area and cortical thickness, whereas trabecular bone of the distal femur showed no differences compared with controls. The greater affectation of cortical bone could explain the major risk of fractures in long bones, pointing to a key role of TGF- $\beta$ pathway in cortical bone maintenance. 


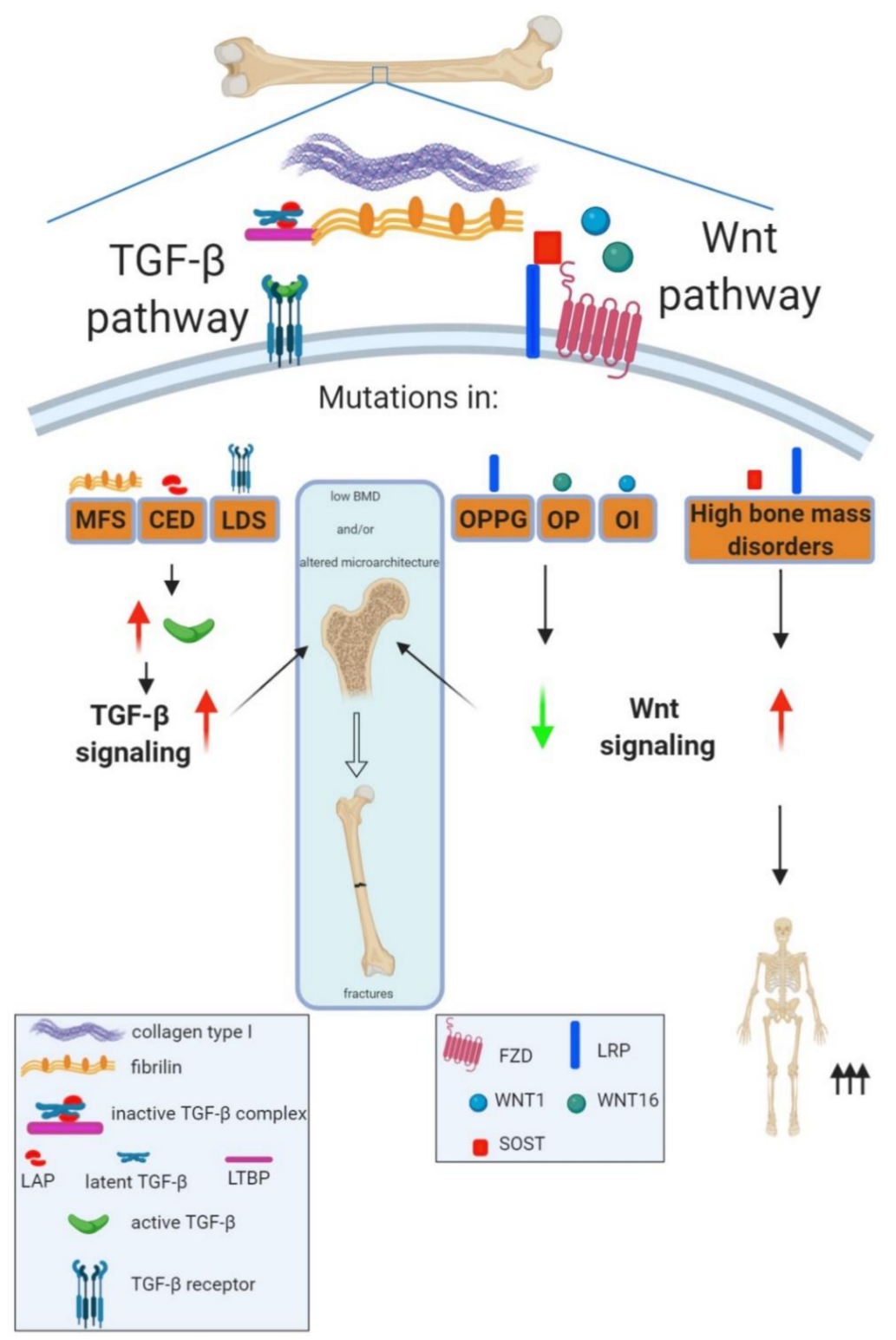

Figure 1. Roles of transforming growth factor beta (TGF- $\beta$ ) and Wnt signaling in bone strength maintenance. Bone strength depends on bone mineral density and bone microarchitecture; disturbances in any of them lead to increased risk of fractures. Human musculoskeletal disorders with mutations in TGF- $\beta$ or Wnt family members have revealed the key role of these pathways in regulating bone strength. Thus, mutations in different TGF- $\beta$ family members leading to an increased pool of active TGF- $\beta$ and therefore an increased TGF- $\beta$ signaling give rise to rare disorders characterized by low bone mineral density, alterations in bone microarchitecture and increased risk of fractures. This is the case of Marfan (MFS) and Loeys-Dietz (LDS) syndromes and Camurati-Engelmann disease (CED), with mutations in FBN1 (Fibrillin-1), TGF $\beta$ receptors (TGF $\beta R 1$ and TGF $\beta R 2$ ) and LAP, respectively. In the case of the Wnt pathway, mutations leading to increased Wnt signaling can cause high bone mass disorders, whereas inactivating mutations of the Wnt pathway are associated to low bone mass disorders with different ranges of severities. Thus, heterozygous mutations in Wnt1 or SNPs in Wnt16 can lead to osteoporosis (OP) whereas homozygous mutations of Wnt1 cause osteogenesis imperfecta (OI). Moreover, autosomal recessive loss of function mutations in LRP5 are known to cause the rare osteoporosis pseudoglioma syndrome (OPPG) characterized by extremely severe childhood onset osteoporosis. For definitions of other abbreviations, please see the main text. Red arrow increased expression; green arrow decreased expression. 
Camurati-Engelman disease (CED), a rare skeletal dysplasia, is caused by mutations in the $\mathrm{N}$-terminal prodomain (LAP) of TGF- $\beta 1$, leading to an increase TGF- $\beta$ signaling [198]. The cortical thickening of the diaphysis of long bones of the upper and lower limbs is the hallmark of the disease. The existence of increase fractures in CED patients is controversial and there are no studies regarding their microarchitecture in which could estimate bone strength. However, a transgenic mouse model of CED exhibiting cortical thickness increased as in humans, showed a higher incidence of long bone fractures along with increased cortical bone porosity [53].

These rare pathologies affecting bone show that overexpression of TGF- $\beta$ signaling pathway deeply affects bone microstructure leading to an increased risk of fractures. Interestingly, cortical bone tissue seems to be especially affected in these pathologies characterized by TGF- $\beta$ signaling hyperactivation, emphasizing TGF- $\beta$ 's crucial role in maintaining cortical bone tissue homeostasis.

In OI, one study that used two distinct mouse models of OI showed that excessive TGF- $\beta$ signaling is an important disease mechanism that contributes to the OI phenotype [199]. Although the precise process that leads to TGF- $\beta$ overactivity has not been worked out yet, it is likely that type I collagen and consequent proteoglycan alterations in OI cause inefficient retention of TGF- $\beta$ in the matrix.

Regarding osteoporosis, several TGF- $\beta$ superfamily members (TGFB1, BMP2, BMP4, and Sclerostin) [200] have been implicated as candidate genes in osteoporosis [201]. Indeed, several polymorphisms in TGF- $\beta 1$, related with higher serum TGF- $\beta 1$ levels and significantly lower bone mass, have been identified in patients with osteoporosis [202]. In addition, another study identified single nucleotide polymorphisms (SNPs) in several TGF- $\beta$ pathway components in patients with osteoporosis (TGFBR1, TGFBR2, Smad2, Smad3, Smad4, and Smad7) [203], but the relevance of these polymorphisms remains to be established.

\subsubsection{Wnt}

The bone-anabolic role of Wnt pathway was revealed by the existence of high bone mass disorders along with the identification of causative gene mutations in key Wnt family members, responsible for Wnt signaling cascade hyperactivation. This was the case of patients with heterozygous gain of function mutations in lipoprotein receptor-related protein 5 (LRP5) (a coreceptor of the Wnt pathway [204]), or loss-of-function mutations of its inhibitor sclerostin [205].

Conversely, loss-of-function mutations in LRP5 cause autosomal recessive osteoporosispseudoglioma syndrome (OPPG) characterized by blindness from birth, very low bone mass in early childhood and consequent increased risk of fractures and bone deformation [128].

In this regard, mutations in the fourth $\beta$-propeller of LRP5 have been associated with early childhood-onset primary osteoporosis [206,207] (Figure 1). Interestingly, lithium, a known Wnt pathway activator (mentioned above) is being currently in a clinical trial for OPPG (ClinicalTrials.gov Identifier: NCT01108068).

Later studies identified that mutations or even variants in the sequence of Wnt ligands can lead to osteoporosis with different ranges of severities [208]. Thus, a genomewide association study (GWAS) identified a specific SNP of Wnt16, which was associated to individuals with decreased cortical bone thickness and forearm BMD as well as increased fractures [209]. In the same way, heterozygous Wnt inactivating mutations can lead to low bone mass and early onset osteoporosis [210-212]. For instance, rare variations in the $W n t 3 a$ and $D K K 1$ genes have been observed in patients with childhood-onset primary osteoporosis [213]. Indeed, Wnt3a-mediated signaling stimulates bone formation and inhibits bone resorption in OVX mice [214], pointing out Wnt3a as a potential therapeutic target for osteoporosis treatment. In particular, Wnt pathway has been reported as a target in osteoporotic treatments [215], the best therapeutic targets for promoting Wnt signaling are the several secreted endogenous inhibitors that constantly exert a negative influence on this pathway to keep it tamed [216]. Thus, by targeting these inhibitors one can activate Wnt signaling and increase bone mass [217]. Inhibition of sclerostin, a Wnt antagonist secreted by osteocytes, leads to decreased bone resorption and increased bone formation. Monoclonal antibodies against sclerostin (romosozumab $[218,219]$ ) have proven in clinical 
trials to be a very efficient osteo-anabolic approach to the treatment of osteoporosis, since they increase bone formation, bone mass, and bone strength [220], therefore decreasing markedly fracture risk in treated patients. Another Wnt ligand related with bone microarchitecture is Wnt1, since mutations in the Wnt1 gene shows reduced trabecular and cortical parameters especially cortical thickness. Interestingly, complete loss of function of Wnt1, due to homozygous or compound heterozygous mutations, leads to moderate-to-severe OI [221].

\section{Conclusions}

In conclusion, bone ECM is tightly related to bone strength, and alterations of different ECM factors could lead to diseases associated with bone fragility. Indeed, the skeleton derives its resistance to fracture from multiple components regulated across several levels of hierarchical organization.

Firstly, the different cells and molecules that compose bone matrix affect bone resistance and, therefore, are implicated in bone fragility. Thus, alterations in bone composition may affect bone mechanical properties and thereby fracture risk. For instance, alterations in type I collagen molecules give rise to OI, a rare disease characterized by bone fragility.

Bone microarchitecture has a crucial role in determining bone resistance. Cortical bone is densely packed, providing the strength and rigidity to bones, whereas trabecular bone is less mineralized, organized to optimize load transfer and disperse the energy of loading. That way, different cortical (tissue mineral density and porosity) and trabecular (the number of trabeculae, trabecular thickness and heterogeneity) parameters are altered in osteoporosis and OI, leading to a more brittle bone.

Then, biophysical properties of the bone ECM, such as the degree and type of collagen crosslinking, the mineral crystal size and their crystallinity, are important determinants of cell behavior. Cells respond differently to denatured collagen than mature, crosslinked collagen fibrils. In osteoporosis, bone quality is affected, since there are considerable changes in collagen crosslinks, which cause loss of bone quality. In OI, the secreted collagen type I can have altered post-translational modification, leading to defective crosslinking. This collagen reduces its ability to correctly bind to other matrix molecules, leading to an altered collagen network that is not able to support mechanical stimuli. Regarding mineral crystal size and alignment, hydroxyapatite crystals are thinner and less well-aligned along collagen fibrils in OI patients compared to controls, leading to decreased mechanical strength and consequent bone fragility.

Finally, ECM components provide a complex network of biochemical and physiological signals to bone cells that contribute to bone homeostasis. In this way, TGF $\beta$ and Wnt signaling pathways have been found to be major contributors to bone strength. Thus, the identification of different bone disorders in which basal signaling of these pathways is altered, has been of crucial relevance in order to decipher the role of TGF $\beta$ and Wnt pathways in bone strength.

All in all, the relative composition, organization and maturity of the mineral and organic bone matrix, together with the cell-matrix signaling, determine the correct development, maintenance and functionality of bone tissue.

Author Contributions: N.A.-S., I.M. and A.I., writing-original draft; A.I. and C.I.R., revising and editing of the manuscript; C.I.R., funding acquisition. All authors have read and agreed to the published version of the manuscript.

Funding: This study was funded by: Instituto de Salud Carlos III through the projects No. PI15/00820 and PI18/00202 (cofunded by European Regional Development Fund/European Social Fund; "A way to make Europe"/"Investing in your future"), Basque Country government under the ELKARTEK program, No. kk-2019/00093/BC and Fundación Mutua Madrileña, No AP165892017.

Conflicts of Interest: The authors declare no conflict of interest. The funders had no role in the collection, analyses or interpretation of data; in the writing of the manuscript, or in the decision to publish the review. 


\begin{tabular}{|c|c|}
\hline advanced glycation end-products & AGEs \\
\hline bone mineral density & BMD \\
\hline bone morphogenetic proteins & BMPs \\
\hline Camurati-Engelman Disease & CED \\
\hline endoplasmic reticulum & ER \\
\hline extracellular matrix & ECM \\
\hline heat shock protein 47 & Hsp47 \\
\hline latency-associated protein & LAP \\
\hline lipoprotein receptor-related protein 5 & LRP 5 \\
\hline Loeys-Dietz syndrome & LDS \\
\hline lysyl hydroxylase 2 & LH2 \\
\hline Marfan Syndrome & MFS \\
\hline matrix metalloproteinases & MMPs \\
\hline mitogen-activated protein kinase & MAPK \\
\hline noncollagenous proteins & NCPs \\
\hline osteocalcin & OC \\
\hline osteogenesis imperfecta & OI \\
\hline osteonectin & ON \\
\hline osteopontin & OPN \\
\hline osteoporosis-pseudoglioma syndrome & OPPG \\
\hline osteoprotegerin & OPG \\
\hline ovariectomized & OVX \\
\hline parathyroid hormone & PTH \\
\hline receptor activator of nuclear factor $\kappa \beta$ ligand & RANKI \\
\hline runt-related transcription factor 2 & Runx2 \\
\hline single nucleotide polimorfism & SNP \\
\hline transforming growth factor beta & TGF- $\beta$ \\
\hline tissue inhibitors of metalloproteinases & TIMPs \\
\hline wingless-type mouse mammary tumor virus integration site family & Wnt \\
\hline
\end{tabular}

\section{References}

1. Bonucci, E. Bone mineralization. Front. Biosci. 2012, 17, 100. [CrossRef]

2. Seeman, E.; Delmas, P.D. Bone Quality-The Material and Structural Basis of Bone Strength and Fragility. N. Engl. J. Med. 2006, 354, 2250-2261. [CrossRef]

3. Fonseca, H.; Moreira-Gonçalves, D.; Coriolano, H.-J.A.; Duarte, J.A. Bone Quality: The Determinants of Bone Strength and Fragility. Sports Med. 2014, 44, 37-53. [CrossRef]

4. Murshed, M. Mechanism of Bone Mineralization. Cold Spring Harb. Perspect. Med. 2018, 8, a031229. [CrossRef]

5. Narisawa, S.; Yadav, M.C.; Millán, J.L. In Vivo Overexpression of Tissue-Nonspecific Alkaline Phosphatase Increases Skeletal Mineralization and Affects the Phosphorylation Status of Osteopontin. J. Bone Miner. Res. 2013, 28, 1587-1598. [CrossRef]

6. Nikitovic, D.; Aggelidakis, J.; Young, M.F.; Iozzo, R.V.; Karamanos, N.K.; Tzanakakis, G.N. The Biology of Small Leucine-rich Proteoglycans in Bone Pathophysiology. J. Biol. Chem. 2012, 287, 33926-33933. [CrossRef] [PubMed]

7. Zhang, J.; Ma, Z.; Yan, K.; Wang, Y.; Yang, Y.; Wu, X. Matrix Gla Protein Promotes the Bone Formation by Up-Regulating Wnt/ $\beta$-Catenin Signaling Pathway. Front. Endocrinol. 2019, 10, 891. [CrossRef]

8. Goltzman, D.; Mannstadt, M.; Marcocci, C. Physiology of the Calcium-Parathyroid Hormone-Vitamin D Axis. Front. Horm. Res. 2018, 50, 1-13. [CrossRef]

9. Poole, K.E.S.; Reeve, J. Parathyroid hormone-A bone anabolic and catabolic agent. Curr. Opin. Pharmacol. 2005, 5, 612-617. [CrossRef] [PubMed] 
10. Christakos, S.; Dhawan, P.; Verstuyf, A.; Verlinden, L.; Carmeliet, G. Vitamin D: Metabolism, Molecular Mechanism of Action, and Pleiotropic Effects. Physiol. Rev. 2016, 96, 365-408. [CrossRef] [PubMed]

11. Follet, H.; Boivin, G.; Rumelhart, C.; Meunier, P. The degree of mineralization is a determinant of bone strength: A study on human calcanei. Bone 2004, 34, 783-789. [CrossRef] [PubMed]

12. Boivin, G.; Meunie, P.J. Changes in bone remodeling rate influence the degree of mineralization of bone which is a determinant of bone strength: Therapeutic implications. Single Mol. Single Cell Seq. 2001, 496, $123-127$.

13. Currey, J. Physical characteristics affecting the tensile failure properties of compact bone. J. Biomech. 1990, 23, 837-844. [CrossRef]

14. Martin, R.M.; Corrêa, P.H.S. Bone quality and osteoporosis therapy. Arq. Bras. Endocrinol. Metabol. 2010, 54, 186-199. [CrossRef] [PubMed]

15. Ricard-Blum, S. The Collagen Family. Cold Spring Harb. Perspect. Biol. 2011, 3, a004978. [CrossRef]

16. Gorski, J.P. Biomineralization of bone: A fresh view of the roles of non-collagenous proteins. Front. Biosci. 2011, 16, 2598-2621. [CrossRef]

17. Garnero, P. The contribution of collagen crosslinks to bone strength. Bonekey Rep. 2012, 1, 182. [CrossRef]

18. Saito, M.; Marumo, K. Collagen cross-links as a determinant of bone quality: A possible explanation for bone fragility in aging, osteoporosis, and diabetes mellitus. Osteoporos. Int. 2010, 21, 195-214. [CrossRef]

19. Florencio-Silva, R.; Sasso, G.R.; Sasso-Cerri, E.; Simões, M.J.; Cerri, P.S. Biology of Bone Tissue: Structure, Function, and Factors That Influence Bone Cells. BioMed Res. Int. 2015, 2015, 421746. [CrossRef]

20. Eriksen, E.F.; Axelrod, D.W.; Melsen, F. Bone Histomorphometry; Raven Press: New York, NY, USA, 1994.

21. Oftadeh, R.; Perez-Viloria, M.; Villa-Camacho, J.C.; Vaziri, A.; Nazarian, A. Biomechanics and Mechanobiology of Trabecular Bone: A Review. J. Biomech. Eng. 2015, 137, 010802-01080215. [CrossRef]

22. Parfitt, A. Misconceptions (2): Turnover is always higher in cancellous than in cortical bone. Bone 2002, 30, 807-809. [CrossRef]

23. Clarke, B. Normal Bone Anatomy and Physiology. Clin. J. Am. Soc. Nephrol. 2008, 3, S131-S139. [CrossRef] [PubMed]

24. Boskey, A. Bone mineral crystal size. Osteoporos. Int. 2003, 14, 16-21. [CrossRef]

25. Fernandes, H.; Mentink, A.; Bank, R.; Stoop, R.; Van Blitterswijk, C.A.; De Boer, J. Endogenous Collagen Influences Differentiation of Human Multipotent Mesenchymal Stromal Cells. Tissue Eng. Part A 2010, 16, 1693-1702. [CrossRef]

26. Ida, T.; Kaku, M.; Kitami, M.; Terajima, M.; Rocabado, J.M.R.; Akiba, Y.; Nagasawa, M.; Yamauchi, M.; Uoshima, K. Extracellular matrix with defective collagen cross-linking affects the differentiation of bone cells. PLOS ONE 2018, 13, e0204306. [CrossRef]

27. Bella, J.; Hulmes, D.J.S. Fibrillar Collagens. In Fibrous Proteins: Structures and Mechanisms; Springer: Cham, Switzerland, 2017; pp. 457-490. [CrossRef]

28. Depalle, B.; Qin, Z.; Shefelbine, S.J.; Buehler, M.J. Influence of cross-link structure, density and mechanical properties in the mesoscale deformation mechanisms of collagen fibrils. J. Mech. Behav. Biomed. Mater. 2015, 52,1-13. [CrossRef]

29. Osterhoff, G.; Morgan, E.F.; Shefelbine, S.J.; Karim, L.; McNamara, L.M.; Augat, P. Bone mechanical properties and changes with osteoporosis. Injury 2016, 47, S11-S20. [CrossRef]

30. Schmidt, F.; Zimmermann, E.; Campbell, G.; Sroga, G.; Püschel, K.; Amling, M.; Tang, S.Y.; Vashishth, D.; Busse, B. Assessment of collagen quality associated with non-enzymatic cross-links in human bone using Fourier-transform infrared imaging. Bone 2017, 97, 243-251. [CrossRef]

31. Jiang, X.; Ye, M.; Liu, G.; Feng, S.; Cui, L.; Zou, H. Method development of efficient protein extraction in bone tissue for proteome analysis. J. Proteome Res. 2007, 6, 2287-2294. [CrossRef]

32. Salmon, C.R.; Tomazela, D.M.; Ruiz, K.G.S.; Foster, B.L.; Leme, A.F.P.; Sallum, E.A.; Somerman, M.J.; Nociti, F.H. Proteomic analysis of human dental cementum and alveolar bone. J. Proteom. 2013, 91, 544-555. [CrossRef]

33. Kim, S.-H.; Turnbull, J.; Guimond, S. Extracellular matrix and cell signalling: The dynamic cooperation of integrin, proteoglycan and growth factor receptor. J. Endocrinol. 2011, 209, 139-151. [CrossRef]

34. Alford, A.I.; Kozloff, K.M.; Hankenson, K.D. Extracellular matrix networks in bone remodeling. Int. J. Biochem. Cell Biol. 2015, 65, 20-31. [CrossRef] [PubMed] 
35. Bouillon, R.; Marcocci, C.; Carmeliet, G.; Bikle, D.D.; White, J.H.; Dawson-Hughes, B.; Lips, P.; Munns, C.F.; Lazaretti-Castro, M.; Giustina, A.; et al. Skeletal and Extraskeletal Actions of Vitamin D: Current Evidence and Outstanding Questions. Endocr. Rev. 2019, 40, 1109-1151. [CrossRef] [PubMed]

36. Fan, Y.; Hanai, J.-I.; Le, P.T.; Bi, R.; Maridas, D.; DeMambro, V.; Figueroa, C.A.; Kir, S.; Zhou, X.; Mannstadt, M.; et al. Parathyroid Hormone Directs Bone Marrow Mesenchymal Cell Fate. Cell Metab. 2017, 25, 661-672. [CrossRef] [PubMed]

37. Almeida, M.; Laurent, M.R.; Dubois, V.; Claessens, F.; O’Brien, C.A.; Bouillon, R.; Vanderschueren, D.; Laurent, M.R. Estrogens and Androgens in Skeletal Physiology and Pathophysiology. Physiol. Rev. 2017, 97, 135-187. [CrossRef] [PubMed]

38. Chande, S.; Bergwitz, C. Role of phosphate sensing in bone and mineral metabolism. Nat. Rev. Endocrinol. 2018, 14, 637-655. [CrossRef]

39. Infante, A.; Rodríguez, C.I. Osteogenesis and aging: Lessons from mesenchymal stem cells. Stem Cell Res. Ther. 2018, 9, 1-7. [CrossRef]

40. Horton, E.R.; Byron, A.; Askari, J.A.; Ng, D.H.J.; Millon-Frémillon, A.; Robertson, J.; Koper, E.J.; Paul, N.R.; Warwood, S.; Knight, D.P.; et al. Definition of a consensus integrin adhesome and its dynamics during adhesion complex assembly and disassembly. Nat. Cell Biol. 2015, 17, 1577-1587. [CrossRef]

41. Li, Z.; Lee, H.; Zhu, C. Molecular mechanisms of mechanotransduction in integrin-mediated cell-matrix adhesion. Exp. Cell Res. 2016, 349, 85-94. [CrossRef]

42. Kechagia, J.Z.; Ivaska, J.; Roca-Cusachs, P. Integrins as biomechanical sensors of the microenvironment. Nat. Rev. Mol. Cell Biol. 2019, 20, 457-473. [CrossRef]

43. Discher, D.E.; Janmey, P.; Wang, Y.-L. Tissue Cells Feel and Respond to the Stiffness of Their Substrate. Science 2005, 310, 1139-1143. [CrossRef]

44. Engler, A.J.; Sen, S.; Sweeney, H.L.; Discher, D.E. Matrix elasticity directs stem cell lineage specification. Cell 2006, 126, 677-689. [CrossRef]

45. Sun, M.; Chi, G.; Xu, J.; Tan, Y.; Xu, J.; Lv, S.; Xu, Z.; Xia, Y.; Li, L.; Li, Y. Extracellular matrix stiffness controls osteogenic differentiation of mesenchymal stem cells mediated by integrin $\alpha 5$. Stem Cell Res. Ther. 2018, 9,1-13. [CrossRef]

46. Chen, B.; Ji, B.; Gao, H. Modeling Active Mechanosensing in Cell-Matrix Interactions. Annu. Rev. Biophys. 2015, 44, 1-32. [CrossRef] [PubMed]

47. Almalki, S.G.; Agrawal, D.K. Effects of matrix metalloproteinases on the fate of mesenchymal stem cells. Stem Cell Res. Ther. 2016, 7, 1-12. [CrossRef] [PubMed]

48. Kasper, G.; Glaeser, J.D.; Geissler, S.; Ode, A.; Tuischer, J.; Matziolis, G.; Perka, C.; Duda, G.N. Matrix Metalloprotease Activity Is an Essential Link Between Mechanical Stimulus and Mesenchymal Stem Cell Behavior. Stem Cells 2007, 25, 1985-1994. [CrossRef] [PubMed]

49. Lozito, T.P.; Jackson, W.M.; Nesti, L.; Tuan, R.S. Human mesenchymal stem cells generate a distinct pericellular zone of MMP activities via binding of MMPs and secretion of high levels of TIMPs. Matrix Biol. 2014, 34, 132-143. [CrossRef]

50. Buxton, P.; Bitar, M.; Gellynck, K.; Parkar, M.; Brown, R.; Young, A.; Knowles, J.; Nazhat, S. Dense collagen matrix accelerates osteogenic differentiation and rescues the apoptotic response to MMP inhibition. Bone 2008, 43, 377-385. [CrossRef]

51. Mauney, J.; Volloch, V. Adult human bone marrow stromal cells regulate expression of their MMPs and TIMPs in differentiation type-specific manner. Matrix Biol. 2010, 29, 3-8. [CrossRef] [PubMed]

52. Paiva, K.B.; Granjeiro, J.M. Matrix Metalloproteinases in Bone Resorption, Remodeling, and Repair. Prog. Mol. Biol. Transl. Sci. 2017, 148, 203-303. [CrossRef] [PubMed]

53. Tang, Y.; Wu, X.; Lei, W.; Pang, L.; Wan, C.; Shi, Z.; Zhao, L.; Nagy, T.R.; Peng, X.; Hu, J.; et al. TGF-beta1-induced migration of bone mesenchymal stem cells couples bone resorption with formation. Nat. Med. 2009, 15, 757-765. [CrossRef] [PubMed]

54. Sternlicht, M.D.; Werb, Z. How Matrix Metalloproteinases Regulate Cell Behavior. Annu. Rev. Cell Dev. Biol. 2001, 17, 463-516. [CrossRef] [PubMed]

55. Karsdal, M.A.; Fjording, M.S.; Foged, N.T.; Delaissé, J.M.; Lochter, A. Transforming growth factor-beta-induced osteoblast elongation regulates osteoclastic bone resorption through a p38 mitogen-activated protein kinase- and matrix metalloproteinase-dependent pathway. J. Biol. Chem. 2001, 276, 39350-39358. [CrossRef] [PubMed] 
56. Pivetta, E.; Scapolan, M.; Pecolo, M.; Wassermann, B.; Abu Rumeileh, I.; Balestreri, L.; Borsatti, E.; Tripodo, C.; Colombatti, A.; Spessotto, P. MMP-13 stimulates osteoclast differentiation and activation in tumour breast bone metastases. Breast Cancer Res. 2011, 13, R105. [CrossRef] [PubMed]

57. Dole, N.S.; Mazur, C.M.; Acevedo, C.; Lopez, J.P.; Monteiro, D.A.; Fowler, T.W.; Gludovatz, B.; Walsh, F.; Regan, J.N.; Messina, S.; et al. Osteocyte-Intrinsic TGF- $\beta$ Signaling Regulates Bone Quality through Perilacunar/Canalicular Remodeling. Cell Rep. 2017, 21, 2585-2596. [CrossRef] [PubMed]

58. Zhang, Y.E. Non-Smad Signaling Pathways of the TGF- $\beta$ Family. Cold Spring Harb. Perspect. Biol. 2016, 9, a022129. [CrossRef]

59. Hering, S.; Isken, E.; Knabbe, C.; Janott, J.; Jost, C.; Pommer, A.; Muhr, G.; Schatz, H.; Pfeiffer, A.F. TGFbeta1 and TGFbeta 2 mRNA and protein expression in human bone samples. Exp. Clin. Endocrinol. Diabetes 2001, 109, 217-226. [CrossRef]

60. Xu, X.; Zheng, L.; Yuan, Q.; Zhen, G.; Crane, J.L.; Zhou, X.; Cao, X. Transforming growth factor- $\beta$ in stem cells and tissue homeostasis. Bone Res. 2018, 6, 2. [CrossRef]

61. Xian, L.; Wu, X.; Pang, L.; Lou, M.; Rosen, C.J.; Qiu, T.; Crane, J.; Frassica, F.J.; Zhang, L.; Rodriguez, J.P.; et al. Matrix IGF-1 maintains bone mass by activation of mTOR in mesenchymal stem cells. Nat. Med. 2012, 18, 1095-1101. [CrossRef]

62. Crane, J.L.; Cao, X. Bone marrow mesenchymal stem cells and TGF- $\beta$ signaling in bone remodeling. J. Clin. Investig. 2014, 124, 466-472. [CrossRef]

63. Kim, J.S.; Kim, J.G.; Moon, M.Y.; Jeon, C.Y.; Won, H.Y.; Kim, H.J.; Jeon, Y.J.; Seo, J.Y.; Kim, J.I.; Kim, J.; et al. Transforming growth factor-beta1 regulates macrophage migration via RhoA. Blood 2006, 108, 1821-1829. [CrossRef] [PubMed]

64. Karst, M.; Gorny, G.; Galvin, R.J.; Oursler, M.J. Roles of stromal cell RANKL, OPG, and M-CSF expression in biphasic TGF-beta regulation of osteoclast differentiation. J. Cell Physiol. 2004, 200, 99-106. [CrossRef] [PubMed]

65. Miyashita, T.; Kawakami, A.; Nakashima, T.; Yamasaki, S.; Tamai, M.; Tanaka, F.; Kamachi, M.; Ida, H.; Migita, K.; Origuchi, T.; et al. Osteoprotegerin (OPG) acts as an endogenous decoy receptor in tumour necrosis factor-related apoptosis-inducing ligand (TRAIL)-mediated apoptosis of fibroblast-like synovial cells. Clin. Exp. Immunol. 2004, 137, 430-436. [CrossRef] [PubMed]

66. Lee, B.; Oh, Y.; Jo, S.; Kim, T.-H.; Ji, J.D. A dual role of TGF- $\beta$ in human osteoclast differentiation mediated by Smad1 versus Smad3 signaling. Immunol. Lett. 2019, 206, 33-40. [CrossRef]

67. Stewart, A.; Guan, H.; Yang, K. BMP-3 promotes mesenchymal stem cell proliferation through the TGF-beta/activin signaling pathway. J. Cell Physiol. 2010, 223, 658-666.

68. Tsuji, K.; Bandyopadhyay, A.; Harfe, B.D.; Cox, K.; Kakar, S.; Gerstenfeld, L.C.; Einhorn, T.A.; Tabin, C.J.; Rosen, V. BMP2 activity, although dispensable for bone formation, is required for the initiation of fracture healing. Nat. Genet. 2006, 38, 1424-1429. [CrossRef]

69. Lee, K.S.; Hong, S.H.; Bae, S.C. Both the Smad and p38 MAPK pathways play a crucial role in Runx2 expression following induction by transforming growth factor-beta and bone morphogenetic protein. Oncogene 2002, 21, 7156-7163. [CrossRef]

70. Ge, C.; Yang, Q.; Zhao, G.; Yu, H.; Kirkwood, K.L.; Franceschi, R.T. Interactions between extracellular signal-regulated kinase 1/2 and p38 MAP kinase pathways in the control of RUNX2 phosphorylation and transcriptional activity. J. Bone Miner. Res. 2012, 27, 538-551. [CrossRef]

71. Macías, I.; Alcorta-Sevillano, N.; Rodríguez, C.I.; Infante, A. Osteoporosis and the Potential of Cell-Based Therapeutic Strategies. Int. J. Mol. Sci. 2020, 21, 1653. [CrossRef]

72. Bonewald, L.F.; Johnson, M.L. Osteocytes, mechanosensing and Wnt signaling. Bone 2008, 42, 606-615. [CrossRef]

73. Glass, D.A.; Karsenty, G. Molecular Bases of the Regulation of Bone Remodeling by the Canonical Wnt Signaling Pathway. Curr. Top. Dev. Biol. 2006, 73, 43-84. [CrossRef] [PubMed]

74. Monroe, D.G.; McGee-Lawrence, M.E.; Oursler, M.J.; Westendorf, J.J. Update on Wnt signaling in bone cell biology and bone disease. Gene 2012, 492, 1-18. [CrossRef] [PubMed]

75. Cadigan, K.M.; Waterman, M.L. TCF/LEFs and Wnt Signaling in the Nucleus. Cold Spring Harb. Perspect. Biol. 2012, 4, a007906. [CrossRef] [PubMed] 
76. Almeida, M.; Han, L.; Bellido, T.; Manolagas, S.C.; Kousteni, S. Wnt proteins prevent apoptosis of both uncommitted osteoblast progenitors and differentiated osteoblasts by beta-catenin-dependent and -independent signaling cascades involving Src/ERK and phosphatidylinositol 3-kinase/AKT. J. Biol. Chem. 2005, 280, 41342-41351. [CrossRef]

77. Cawthorn, W.P.; Bree, A.J.; Yao, Y.; Du, B.; Hemati, N.; Martinez-Santibañez, G.; MacDougald, O.A. Wnt6, Wnt10a and Wnt10b inhibit adipogenesis and stimulate osteoblastogenesis through a $\beta$-catenin-dependent mechanism. Bone 2012, 50, 477-489. [CrossRef]

78. Visweswaran, M.; Pohl, S.; Arfuso, F.; Newsholme, P.; Dilley, R.J.; Pervaiz, S.; Dharmarajan, A.M. Multi-lineage differentiation of mesenchymal stem cells-To Wnt, or not Wnt. Int. J. Biochem. Cell Biol. 2015, 68, $139-147$. [CrossRef] [PubMed]

79. Maeda, K.; Kobayashi, Y.; Koide, M.; Uehara, S.; Okamoto, M.; Ishihara, A.; Kayama, T.; Saito, M.; Marumo, K. The Regulation of Bone Metabolism and Disorders by Wnt Signaling. Int. J. Mol. Sci. 2019, 20, 5525. [CrossRef]

80. Akkawi, I.; Zmerly, H. Osteoporosis: Current Concepts. Joints 2018, 6, 122-127. [CrossRef]

81. Lorentzon, M.; Cummings, S.R. Osteoporosis: The evolution of a diagnosis. J. Intern. Med. 2015, $277,650-661$. [CrossRef]

82. Ji, M.-X.; Yu, Q. Primary osteoporosis in postmenopausal women. Chronic Dis. Transl. Med. 2015, 1, 9-13. [CrossRef]

83. Tian, L.; Yang, R.; Wei, L.; Liu, J.; Yang, Y.; Shao, F.; Ma, W.; Li, T.; Wang, Y.; Guo, T. Prevalence of osteoporosis and related lifestyle and metabolic factors of postmenopausal women and elderly men: A cross-sectional study in Gansu province, Northwestern of China. Medicine 2017, 96, e8294. [CrossRef] [PubMed]

84. Hernlund, E.; Svedbom, A.; Ivergard, M.; Compston, J.; Cooper, C.; Stenmark, J.; McCloskey, E.V.; Jonsson, B.; Kanis, J.A. Osteoporosis in the European Union: Medical management, epidemiology and economic Burden : A report prepared in collaboration with the International Osteoporosis Foundation (IOF) and the European Federation of Pharmaceutical Industry Associations (EFPIA). Arch. Osteoporos. 2013, 8, 136. [CrossRef] [PubMed]

85. Pisani, P.; Renna, M.D.; Conversano, F.; Casciaro, E.; Di Paola, M.; Quarta, E.; Muratore, M.; Casciaro, S. Major osteoporotic fragility fractures: Risk factor updates and societal impact. World J. Orthop. 2016, 7, 171-181. [CrossRef] [PubMed]

86. Sözen, T.; Özış1k, L.; Başaran, N. An overview and management of osteoporosis. Eur. J. Rheumatol. 2017, 4, 46-56. [CrossRef] [PubMed]

87. Hofbauer, L.C.; Lorenz, C.H. Osteoporosis: Now and the future. Endocr. Abstr. 2013, 377, $1276-1287$. [CrossRef]

88. Porter, J.L.; Varacallo, M. Osteoporosis; StatPearls: St. Petersburg, FL, USA, 2020.

89. Cranney, A.; Jamal, S.A.; Tsang, J.F.; Josse, R.G.; Leslie, W.D. Low bone mineral density and fracture burden in postmenopausal women. CMAJ 2007, 177, 575-580. [CrossRef]

90. Bouxsein, M.L. Bone quality: Where do we go from here? Osteoporos. Int. 2003, 14, 118-127. [CrossRef]

91. Misof, B.M.; Gamsjaeger, S.; Cohen, A.; Hofstetter, B.; Roschger, P.; Stein, E.; Nickolas, T.L.; Rogers, H.F.; Dempster, D.; Zhou, H.; et al. Bone material properties in premenopausal women with idiopathic osteoporosis. J. Bone Miner. Res. 2012, 27, 2551-2561. [CrossRef]

92. Kurt-Sirin, O.; Yilmaz-Aydoğan, H.; Uyar, M.; Seyhan, M.-F.; Isbir, T.; Can, A. Combined effects of collagen type I alpha1 (COL1A1) Sp1 polymorphism and osteoporosis risk factors on bone mineral density in Turkish postmenopausal women. Gene 2014, 540, 226-231. [CrossRef]

93. Wu, J.; Yu, M.; Zhou, Y. Association of collagen type I alpha $1+1245 \mathrm{G} / \mathrm{T}$ polymorphism and osteoporosis risk in post-menopausal women: A meta-analysis. Int. J. Rheum. Dis. 2017, 20, 903-910. [CrossRef]

94. Acerbo, A.S.; Kwaczala, A.T.; Yang, L.; Judex, S.; Miller, L.M. Alterations in Collagen and Mineral Nanostructure Observed in Osteoporosis and Pharmaceutical Treatments Using Simultaneous Smalland Wide-Angle X-ray Scattering. Calcif. Tissue Int. 2014, 95, 446-456. [CrossRef] [PubMed]

95. Sroga, G.E.; Vashishth, D. Effects of Bone Matrix Proteins on Fracture and Fragility in Osteoporosis. Curr. Osteoporos. Rep. 2012, 10, 141-150. [CrossRef] [PubMed]

96. Licini, C.; Vitale-Brovarone, C.; Mattioli-Belmonte, M. Collagen and non-collagenous proteins molecular crosstalk in the pathophysiology of osteoporosis. Cytokine Growth Factor Rev. 2019, 49, 59-69. [CrossRef] [PubMed] 
97. Zhang, B.; Dai, J.; Wang, H.; Wei, H.; Zhao, J.; Guo, Y.; Fan, K. Anti-osteopontin monoclonal antibody prevents ovariectomy-induced osteoporosis in mice by promotion of osteoclast apoptosis. Biochem. Biophys. Res. Commun. 2014, 452, 795-800. [CrossRef]

98. Chang, I.-C.; Chiang, T.-I.; Yeh, K.-T.; Lee, H.; Cheng, Y.-W. Increased serum osteopontin is a risk factor for osteoporosis in menopausal women. Osteoporos. Int. 2010, 21, 1401-1409. [CrossRef]

99. Fodor, D.; Bondor, C.; Albu, A.; Simon, S.-P.; Crăciun, A.M.; Muntean, L. The Value of Osteopontin in the Assessment of Bone Mineral Density Status in Postmenopausal Women. J. Investig. Med. 2013, 61, 15-21. [CrossRef]

100. Singh, S.; Kumar, D.; Lal, A.K. Serum Osteocalcin as a Diagnostic Biomarker for Primary Osteoporosis in Women. J. Clin. Diagn. Res. 2015, 9, RC04-RC07. [CrossRef]

101. Liu, Z.; Chen, R.; Jiang, Y.; Yang, Y.; He, L.; Luo, C.; Dong, J.; Rong, L. A meta-analysis of serum osteocalcin level in postmenopausal osteoporotic women compared to controls. BMC Musculoskelet. Disord. 2019, $20,532$. [CrossRef]

102. Lumachi, F.; Ermani, M.; Camozzi, V.; Tombolan, V.; Luisetto, G. Changes of Bone Formation Markers Osteocalcin and Bone-Specific Alkaline Phosphatase in Postmenopausal Women with Osteoporosis. Ann. N. Y. Acad. Sci. 2009, 1173, E60-E63. [CrossRef]

103. Delany, A.M.; Kalajzic, I.; Bradshaw, A.D.; Sage, E.H.; Canalis, E. Osteonectin-Null Mutation Compromises Osteoblast Formation, Maturation, and Survival. Endocrinology 2003, 144, 2588-2596. [CrossRef]

104. Delany, A.M.; Amling, M.; Priemel, M.; Howe, C.; Baron, R.; Canalis, E. Osteopenia and decreased bone formation in osteonectin-deficient mice. J. Clin. Investig. 2000, 105, 1325. [CrossRef] [PubMed]

105. Delany, A.M.; McMahon, D.J.; Powell, J.S.; Greenberg, D.A.; Kurland, E.S. Osteonectin/SPARC polymorphisms in Caucasian men with idiopathic osteoporosis. Osteoporos. Int. 2008, 19, 969-978. [CrossRef] [PubMed]

106. Garnero, P.; Delmas, P.D. Contribution of bone mineral density and bone turnover markers to the estimation of risk of osteoporotic fracture in postmenopausal women. J. Musculoskelet. Neuronal Interact. 2004, 4, 50-63. [PubMed]

107. Sroga, G.E.; Vashishth, D. Phosphorylation of Extracellular Bone Matrix Proteins and Its Contribution to Bone Fragility. J. Bone Miner. Res. 2018, 33, 2214-2229. [CrossRef]

108. Marini, J.C.; Forlino, A.; Bächinger, H.P.; Bishop, N.J.; Byers, P.H.; Paepe, A.; Fassier, F.; Fratzl-Zelman, N.; Kozloff, K.M.; Krakow, D.; et al. Osteogenesis imperfecta. Nat. Rev. Dis. Prim. 2017, 3, 17052. [CrossRef]

109. Moosa, S.; Yamamoto, G.L.; Garbes, L.; Keupp, K.; Beleza-Meireles, A.; Moreno, C.A.; Valadares, E.R.; De Sousa, S.B.; Maia, S.; Saraiva, J.; et al. Autosomal-Recessive Mutations in MESD Cause Osteogenesis Imperfecta. Am. J. Hum. Genet. 2019, 105, 836-843. [CrossRef]

110. Roughley, P.J.; Rauch, F.; Glorieux, F.H. Osteogenesis imperfecta-Clinical and molecular diversity. Eur. Cell Mater. 2003, 5, 41-47. [CrossRef]

111. Singer, R.B.; Ogston, S.A.; Paterson, C.R. Mortality in various types of osteogenesis imperfecta. J. Insur. Med. 2001, 33, 216-220.

112. Boyde, A.; Travers, R.; Glorieux, F.H.; Jones, S.J. The mineralization density of iliac crest bone from children with osteogenesis imperfecta. Calcif. Tissue Int. 1999, 64, 185-190. [CrossRef]

113. Roschger, P.; Fratzl, P.; Misof, B.M.; Glorieux, F.H.; Klaushofer, K.; Rauch, F. Evidence that Abnormal High Bone Mineralization in Growing Children with Osteogenesis Imperfecta is not Associated with Specific Collagen Mutations. Calcif. Tissue Int. 2008, 82, 263-270. [CrossRef]

114. Fratzl-Zelman, N.; Morello, R.; Lee, B.; Rauch, F.; Glorieux, F.; Misof, B.; Klaushofer, K.; Roschger, P. CRTAP deficiency leads to abnormally high bone matrix mineralization in a murine model and in children with osteogenesis imperfecta type VII. Bone 2010, 46, 820-826. [CrossRef] [PubMed]

115. Farber, C.R.; Reich, A.; Barnes, A.M.; Becerra, P.; Rauch, F.; Cabral, W.A.; Bae, A.; Quinlan, A.; Glorieux, F.H.; Clemens, T.L.; et al. A novel IFITM5 mutation in severe atypical osteogenesis imperfecta type VI impairs osteoblast production of pigment epithelium-derived factor. J. Bone Miner. Res. 2014, 29, 1402-1411. [CrossRef] [PubMed]

116. Venturi, G.; Gandini, A.; Monti, E.; Carbonare, L.D.; Corradi, M.; Vincenzi, M.; Valenti, M.T.; Valli, M.; Pelilli, E.; Boner, A.; et al. Lack of expression ofSERPINF1, the gene coding for pigment epithelium-derived factor, causes progressively deforming osteogenesis imperfecta with normal type I collagen. J. Bone Miner. Res. 2012, 27, 723-728. [CrossRef] [PubMed] 
117. Glorieux, F.H.; Rauch, F.; Plotkin, H.; Ward, L.; Travers, R.; Roughley, P.; Lalic, L.; Glorieux, D.F.; Fassier, F.; Bishop, N.J. Type V Osteogenesis Imperfecta: A New Form of Brittle Bone Disease. J. Bone Miner. Res. 2000, 15, 1650-1658. [CrossRef]

118. Glorieux, F.H.; Ward, L.M.; Rauch, F.; Lalic, L.; Roughley, P.J.; Travers, R. Osteogenesis Imperfecta Type VI: A Form of Brittle Bone Disease with a Mineralization Defect. J. Bone Miner. Res. 2002, 17, 30-38. [CrossRef]

119. Reich, A.; Bae, A.S.; Barnes, A.M.; Cabral, W.A.; Hinek, A.; Stimec, J.; Hill, S.C.; Chitayat, D.; Marini, J.C. Type V OI primary osteoblasts display increased mineralization despite decreased COL1A1 expression. J. Clin. Endocrinol. Metab. 2014, 100, E325-E332. [CrossRef]

120. Fratzl-Zelman, N.; Schmidt, I.; Roschger, P.; Roschger, A.; Glorieux, F.; Klaushofer, K.; Wagermaier, W.; Rauch, F.; Fratzl, P. Unique micro- and nano-scale mineralization pattern of human osteogenesis imperfecta type VI bone. Bone 2015, 73, 233-241. [CrossRef]

121. Morello, R. Osteogenesis imperfecta and therapeutics. Matrix Biol. 2018, 71-72, 294-312. [CrossRef]

122. Dickson, I.; Millar, E.; Veis, A. Evidence for abnormality of bone-matrix proteins in osteogenesis imperfecta. Lancet 1975, 306, 586-587. [CrossRef]

123. Marini, J.C.; Reich, A.; Smith, S.M. Osteogenesis imperfecta due to mutations in non-collagenous genes: Lessons in the biology of bone formation. Curr. Opin. Pediatr. 2014, 26, 500-507. [CrossRef]

124. Boraschi-Diaz, I.; Tauer, J.T.; El Rifai, O.; Guillemette, D.; Lefebvre, G.; Rauch, F.; Ferron, M.; Komarova, S.V. Metabolic phenotype in the mouse model of osteogenesis imperfecta. J. Endocrinol. 2017, 234, 279-289. [CrossRef] [PubMed]

125. Vetter, U.; Fisher, L.; Mintz, K.; Kopp, J.; Tuross, N.; Termine, J.; Robey, P.G. Osteogenesis imperfecta: Changes in noncollagenous proteins in bone. J. Bone Miner. Res. 2009, 6, 501-505. [CrossRef] [PubMed]

126. Dyne, K.M.; Valli, M.; Forlino, A.; Mottes, M.; Kresse, H.; Cetta, G. Deficient expression of the small proteoglycan decorin in a case of severe/lethal osteogenesis imperfecta. Am. J. Med Genet. 1996, 63, 161-166. [CrossRef]

127. Fedarko, N.S.; Moerike, M.; Brenner, R.; Robey, P.G.; Vetter, U. Extracellular matrix formation by osteoblasts from patients with osteogenesis imperfecta. J. Bone Miner. Res. 2009, 7, 921-930. [CrossRef] [PubMed]

128. Gong, Y.; Slee, R.B.; Fukai, N.; Rawadi, G.; Roman-Roman, S.; Reginato, A.M.; Wang, H.; Cundy, T.; Glorieux, F.H.; Lev, D.; et al. LDL Receptor-Related Protein 5 (LRP5) Affects Bone Accrual and Eye Development. Cell 2001, 107, 513-523. [CrossRef]

129. Rosset, E.M.; Bradshaw, A.D. SPARC/osteonectin in mineralized tissue. Matrix Biol. 2016, 78-87. [CrossRef]

130. Fedarko, N.S.; Robey, P.G.; Vetter, U.K. Extracellular matrix stoichiometry in osteoblasts from patients with osteogenesis imperfecta. J. Bone Miner. Res. 2009, 10, 1122-1129. [CrossRef]

131. Bishop, N.J. Bone Material Properties in Osteogenesis Imperfecta. J. Bone Miner. Res. 2016, 31, $699-708$. [CrossRef]

132. Sharma, D.; Larriera, A.I.; Palacio-Mancheno, P.E.; Gatti, V.; Fritton, J.C.; Bromage, T.G.; Cardoso, L.; Doty, S.B.; Fritton, S.P. The effects of estrogen deficiency on cortical bone microporosity and mineralization. Bone 2018, 110, 1-10. [CrossRef]

133. Rocabado, J.M.R.; Kaku, M.; Nozaki, K.; Ida, T.; Kitami, M.; Aoyagi, Y.; Uoshima, K. A multi-factorial analysis of bone morphology and fracture strength of rat femur in response to ovariectomy. J. Orthop. Surg. Res. 2018, 13, 1-10. [CrossRef]

134. Yeh, P.-S.; Lee, Y.-W.; Chang, W.-H.; Wang, W.; Wang, J.-L.; Liu, S.-H.; Chen, R.-M. Biomechanical and tomographic differences in the microarchitecture and strength of trabecular and cortical bone in the early stage of male osteoporosis. PLoS ONE 2019, 14, e0219718. [CrossRef] [PubMed]

135. McNamara, L.M. Perspective on post-menopausal osteoporosis: Establishing an interdisciplinary understanding of the sequence of events from the molecular level to whole bone fractures. J. R. Soc. Interface 2010, 7, 353-372. [CrossRef]

136. Krause, M.; Hubert, J.; Deymann, S.; Hapfelmeier, A.; Wulff, B.; Petersik, A.; Puschel, K.; Amling, M.; Hawellek, T.; Frosch, K.-H. Bone microarchitecture of the tibial plateau in skeletal health and osteoporosis. Knee 2018, 25, 559-567. [CrossRef] [PubMed]

137. Sandino, C.; McErlain, D.D.; Schipilow, J.; Boyd, S.K. Mechanical stimuli of trabecular bone in osteoporosis: A numerical simulation by finite element analysis of microarchitecture. J. Mech. Behav. Biomed. Mater. 2017, 66, 19-27. [CrossRef] [PubMed] 
138. Nijhuis, W.H.; Eastwood, D.M.; Allgrove, J.; Hvid, I.; Weinans, H.H.; Bank, R.A.; Sakkers, R. Current concepts in osteogenesis imperfecta: Bone structure, biomechanics and medical management. J. Child. Orthop. 2019, 13, 1-11. [CrossRef] [PubMed]

139. Folkestad, L.; Hald, J.D.; Hansen, S.; Gram, J.; Langdahl, B.; Abrahamsen, B.; Brixen, K. Bone geometry, density, and microarchitecture in the distal radius and tibia in adults with osteogenesis imperfecta type I assessed by high-resolution pQCT. J. Bone Miner. Res. 2012, 27, 1405-1412. [CrossRef] [PubMed]

140. Abidin, A.Z.; Jameson, J.; Molthen, R.; Wismüller, A. Classification of micro-CT images using 3D characterization of bone canal patterns in human osteogenesis imperfecta. Med. Imaging 2017 Comput. Aided Diagn. 2017, 10134, 1013413. [CrossRef]

141. Imbert, L.; Aurégan, J.-C.; Pernelle, K.; Hoc, T. Mechanical and mineral properties of osteogenesis imperfecta human bones at the tissue level. Bone 2014, 65, 18-24. [CrossRef]

142. Kocijan, R.; Muschitz, C.; Haschka, J.; Hans, D.; Nia, A.; Geroldinger, A.; Ardelt, M.; Wakolbinger, R.; Resch, H. Bone structure assessed by HR-pQCT, TBS and DXL in adult patients with different types of osteogenesis imperfecta. Osteoporos. Int. 2015, 26, 2431-2440. [CrossRef]

143. Braga, V.; Gatti, D.; Rossini, M.; Colapietro, F.; Battaglia, E.; Viapiana, O.; Adami, S. Bone turnover markers in patients with osteogenesis imperfecta. Bone 2004, 34, 1013-1016. [CrossRef]

144. Saito, M.; Fujii, K.; Marumo, K. Degree of Mineralization-related Collagen Crosslinking in the Femoral Neck Cancellous Bone in Cases of Hip Fracture and Controls. Calcif. Tissue Int. 2006, 79, 160-168. [CrossRef] [PubMed]

145. Oxlund, H.; Sekilde, L.; Ørtoft, G. Reduced concentration of collagen reducible cross links in human trabecular bone with respect to age and osteoporosis. Bone 1996, 19, 479-484. [CrossRef]

146. Köwitz, J.; Knippel, M.; Schuhr, T.; Mach, J. Alteration in the Extent of Collagen I Hydroxylation, Isolated from Femoral Heads of Women with a Femoral Neck Fracture Caused by Osteoporosis. Calcif. Tissue Int. 1997, 60, 501-505. [CrossRef] [PubMed]

147. Saito, M.; Fujii, K.; Soshi, S.; Tanaka, T. Reductions in degree of mineralization and enzymatic collagen cross-links and increases in glycation-induced pentosidine in the femoral neck cortex in cases of femoral neck fracture. Osteoporos. Int. 2006, 17, 986-995. [CrossRef] [PubMed]

148. Yang, D.-H.; Chiang, T.-I.; Chang, I.-C.; Lin, F.-H.; Wei, C.-C.; Cheng, Y.-W. Increased Levels of Circulating Advanced Glycation End-Products in Menopausal Women with Osteoporosis. Int. J. Med Sci. 2014, 11, 453-460. [CrossRef] [PubMed]

149. Dong, X.N.; Qin, A.; Xu, J.; Wang, X. In situ accumulation of advanced glycation endproducts (AGEs) in bone matrix and its correlation with osteoclastic bone resorption. Bone 2011, 49, 174-183. [CrossRef]

150. Yamamoto, Y.; Kato, I.; Doi, T.; Yonekura, H.; Ohashi, S.; Takeuchi, M.; Watanabe, T.; Yamagishi, S.; Sakurai, S.; Takasawa, S.; et al. Development and prevention of advanced diabetic nephropathy in RAGE-overexpressing mice. J. Clin. Investig. 2001, 108, 261-268. [CrossRef]

151. Sanguineti, R.; Storace, D.; Monacelli, F.; Federici, A.; Odetti, P. Pentosidine effects on human osteoblasts in vitro. Ann. N. Y. Acad. Sci. 2008, 1126, 166-172. [CrossRef]

152. Alikhani, M.; Alikhani, Z.; Boyd, C.; MacLellan, C.M.; Raptis, M.; Liu, R.; Pischon, N.; Trackman, P.C.; Gerstenfeld, L.; Graves, D.T. Advanced glycation end products stimulate osteoblast apoptosis via the MAP kinase and cytosolic apoptotic pathways. Bone 2007, 40, 345-353. [CrossRef]

153. Willett, T.; Pasquale, J.; Grynpas, M.D. Collagen Modifications in Postmenopausal Osteoporosis: Advanced Glycation Endproducts May Affect Bone Volume, Structure and Quality. Curr. Osteoporos. Rep. 2014, 12, 329-337. [CrossRef]

154. Farlay, D.; Bala, Y.; Rizzo, S.; Bare, S.; Lappe, J.; Recker, R.; Boivin, G. Bone remodeling and bone matrix quality before and after menopause in healthy women. Bone 2019, 128, 115030. [CrossRef] [PubMed]

155. Boivin, G.; Bala, Y.; Doublier, A.; Farlay, D.; Ste-Marie, L.; Meunier, P.J.; Delmas, P. The role of mineralization and organic matrix in the microhardness of bone tissue from controls and osteoporotic patients. Bone 2008, 43, 532-538. [CrossRef] [PubMed]

156. Cabral, W.A.; Perdivara, I.; Weis, M.; Terajima, M.; Blissett, A.R.; Chang, W.; Perosky, J.E.; Makareeva, E.N.; Mertz, E.L.; Leikin, S.; et al. Abnormal Type I Collagen Post-translational Modification and Crosslinking in a Cyclophilin B KO Mouse Model of Recessive Osteogenesis Imperfecta. PLoS Genet. 2014, 10, e1004465. [CrossRef] [PubMed]

157. Forlino, A.; Marini, J.C. Osteogenesis imperfecta. Lancet 2016, 387, 1657-1671. [CrossRef] 
158. Ito, S.; Nagata, K. Roles of the endoplasmic reticulum-resident, collagen-specific molecular chaperone Hsp47 in vertebrate cells and human disease. J. Biol. Chem. 2019, 294, 2133-2141. [CrossRef]

159. Lindert, U.; Weis, M.A.; Rai, J.; Seeliger, F.; Hausser, I.; Leeb, T.; Eyre, D.; Rohrbach, M.; Giunta, C. Molecular Consequences of theSERPINH1/HSP47 Mutation in the Dachshund Natural Model of Osteogenesis Imperfecta. J. Biol. Chem. 2015, 290, 17679-17689. [CrossRef]

160. Zhou, P.; Liu, Y.; Lv, F.; Nie, M.; Jiang, Y.; Wang, O.; Xia, W.; Xing, X.; Li, M. Novel Mutations in FKBP10 and PLOD2 Cause Rare Bruck Syndrome in Chinese Patients. PLoS ONE 2014, 9, e107594. [CrossRef]

161. Lv, F.; Xu, X.; Song, Y.; Li, L.; Wang, J.; Yang, H.; Wang, O.; Jiang, Y.; Xia, W.; Xing, X.; et al. Novel Mutations in PLOD2 Cause Rare Bruck Syndrome. Calcif. Tissue Int. 2017, 102, 296-309. [CrossRef]

162. Mumm, S.; Gottesman, G.S.; Wenkert, D.; Campeau, P.M.; Nenninger, A.; Huskey, M.; Bijanki, V.N.; Novack, D.V.; Barnes, A.M.; Marini, J.C.; et al. Bruck syndrome 2 variant lacking congenital contractures and involving a novel compound heterozygous PLOD2 mutation. Bone 2020, 130, 115047. [CrossRef]

163. Eyre, D.R.; Weis, M.A. Bone Collagen: New Clues to Its Mineralization Mechanism from Recessive Osteogenesis Imperfecta. Calcif. Tissue Int. 2013, 93, 338-347. [CrossRef]

164. Alanay, Y.; Avaygan, H.; Camacho, N.; Utine, G.E.; Boduroglu, K.; Aktas, D.; Alikasifoglu, M.; Tuncbilek, E.; Orhan, D.; Bakar, F.T.; et al. Mutations in the gene encoding the RER protein FKBP65 cause autosomal-recessive osteogenesis imperfecta. Am. J. Hum. Genet. 2010, 86, 551-559. [CrossRef] [PubMed]

165. Gjaltema, R.A.F.; Van Der Stoel, M.M.; Boersema, M.; Bank, R.A. Disentangling mechanisms involved in collagen pyridinoline cross-linking: The immunophilin FKBP65 is critical for dimerization of lysyl hydroxylase 2. Proc. Natl. Acad. Sci. USA 2016, 113, 7142-7147. [CrossRef] [PubMed]

166. Lietman, C.D.; Rajagopal, A.; Homan, E.P.; Munivez, E.; Jiang, M.M.; Bertin, T.K.; Chen, Y.; Hicks, J.; Weis, M.; Eyre, D.; et al. Connective tissue alterations in Fkbp10-/- mice. Hum. Mol. Genet. 2014, 23, 4822-4831. [CrossRef]

167. Barnes, A.M.; Cabral, W.A.; Weis, M.; Makareeva, E.; Mertz, E.L.; Leikin, S.; Eyre, D.; Trujillo, C.; Marini, J.C. Absence ofFKBP10in recessive type XI osteogenesis imperfecta leads to diminished collagen cross-linking and reduced collagen deposition in extracellular matrix. Hum. Mutat. 2012, 33, 1589-1598. [CrossRef] [PubMed]

168. Fratzl, P.; Paris, O.; Klaushofer, K.; Landis, W.J. Bone mineralization in an osteogenesis imperfecta mouse model studied by small-angle x-ray scattering. J. Clin. Investig. 1996, 97, 396-402. [CrossRef] [PubMed]

169. Vanleene, M.; Porter, A.E.; Guillot, P.V.; Boyde, A.; Oyen, M.L.; Shefelbine, S. Ultra-structural defects cause low bone matrix stiffness despite high mineralization in osteogenesis imperfecta mice. Bone 2012, 50, 1317-1323. [CrossRef]

170. Vetter, U.; Eanes, E.D.; Kopp, J.B.; Termine, J.D.; Robey, P.G. Changes in apatite crystal size in bones of patients with osteogenesis imperfecta. Calcif. Tissue Int. 1991, 49, 248-250. [CrossRef]

171. Fratzl-Zelman, N.; Schmidt, I.; Roschger, P.; Glorieux, F.H.; Klaushofer, K.; Fratzl, P.; Rauch, F.; Wagermaier, W. Mineral particle size in children with osteogenesis imperfecta type I is not increased independently of specific collagen mutations. Bone 2014, 60, 122-128. [CrossRef]

172. Popov, C.; Radic, T.; Haasters, F.; Prall, W.C.; Aszodi, A.; Gullberg, D.; Schieker, M.; Docheva, D. Integrins $\alpha 2 \beta 1$ and $\alpha 11 \beta 1$ regulate the survival of mesenchymal stem cells on collagen I. Cell Death Dis. 2011, 2, e186. [CrossRef]

173. Shoulders, M.D.; Raines, R.T. Collagen structure and stability. Annu. Rev. Biochem. 2009, 78, 929-958. [CrossRef]

174. Yigit, S.; Yu, H.; An, B.; Hamaia, S.; Farndale, R.W.; Kaplan, D.L.; Lin, Y.S.; Brodsky, B. Mapping the Effect of Gly Mutations in Collagen on $\alpha 2 \beta 1$ Integrin Binding. J. Biol. Chem. 2016, 291, 19196-19207. [CrossRef]

175. Hamaia, S.; Farndale, R.W. Integrin Recognition Motifs in the Human Collagens. Adv. Exp. Med. Biol. 2014, 819, 127-142. [CrossRef] [PubMed]

176. Grigoryan, A.V.; Dimitrova, A.A.; Kostov, K.; Russeva, A.L.; Atanasova, M.A.; Blagev, A.B.; Betova, T.M.; Trifonov, R.G. Changes of Serum Concentrations of Alkaline Phosphatase and Metalloproteinase-9 in an Ovariectomized Wistar Rat Model of Osteoporosis. J. Biomed. Clin. Res. 2017, 10, 32-36. [CrossRef]

177. Bolton, C.; Stone, M.D.; Edwards, P.; Duckers, J.; Evans, W.; Shale, D. Circulating matrix metalloproteinase-9 and osteoporosis in patients with chronic obstructive pulmonary disease. Chronic Respir. Dis. 2009, 6, 81-87. [CrossRef] [PubMed] 
178. Luo, X.-H.; Guo, L.-J.; Shan, P.-F.; Xie, H.; Wu, X.-P.; Zhang, H.; Cao, X.-Z.; Yuan, L.-Q.; Liao, E.-Y. Relationship of circulating MMP-2, MMP-1, and TIMP-1 levels with bone biochemical markers and bone mineral density in postmenopausal Chinese women. Osteoporos. Int. 2006, 17, 521-526. [CrossRef]

179. Rubino, M.T.; Agamennone, M.; Campestre, C.; Campiglia, P.; Cremasco, V.; Faccio, R.; Laghezza, A.; Loiodice, F.; Maggi, D.; Panza, E.; et al. Biphenyl sulfonylamino methyl bisphosphonic acids as inhibitors of matrix metalloproteinases and bone resorption. Chem. Med. Chem. 2011, 6, 1258-1268. [CrossRef]

180. Tauro, M.; Laghezza, A.; Loiodice, F.; Agamennone, M.; Campestre, C.; Tortorella, P. Arylamino methylene bisphosphonate derivatives as bone seeking matrix metalloproteinase inhibitors. Bioorganic Med. Chem. 2013, 21, 6456-6465. [CrossRef] [PubMed]

181. Arkadash, V.; Yosef, G.; Shirian, J.; Cohen, I.; Horev, Y.; Grossman, M.; Sagi, I.; Radisky, E.S.; Shifman, J.M.; Papo, N. Development of High Affinity and High Specificity Inhibitors of Matrix Metalloproteinase 14 through Computational Design and Directed Evolution. J. Biol. Chem. 2017, 292, 3481-3495. [CrossRef] [PubMed]

182. Hopkins, D.R.; Keles, S.; Greenspan, D.S. The bone morphogenetic protein 1/Tolloid-like metalloproteinases. Matrix Biol. 2007, 26, 508-523. [CrossRef]

183. Asharani, P.; Keupp, K.; Semler, O.; Wang, W.; Li, Y.; Thiele, H.; Yigit, G.; Pohl, E.; Becker, J.; Frommolt, P.; et al. Attenuated BMP1 Function Compromises Osteogenesis, Leading to Bone Fragility in Humans and Zebrafish. Am. J. Hum. Genet. 2012, 90, 661-674. [CrossRef]

184. Martínez-Glez, V.; Valencia, M.; Caparrós-Martín, J.A.; Aglan, M.; Temtamy, S.; Tenorio, J.; Pulido, V.; Lindert, U.; Rohrbach, M.; Eyre, D.; et al. Identification of a mutation causing deficient BMP1/mTLD proteolytic activity in autosomal recessive osteogenesis imperfecta. Hum. Mutat. 2012, 33, 343-350. [CrossRef] [PubMed]

185. Garrigue-Antar, L.; Hartigan, N.; Kadler, K.E.; Lee, H.C.; Bernstein, H.D. Post-translational Modification of Bone Morphogenetic Protein-1 Is Required for Secretion and Stability of the Protein. J. Biol. Chem. 2002, 277, 43327-43334. [CrossRef] [PubMed]

186. Muir, A.M.; Ren, Y.; Butz, D.H.; Davis, N.A.; Blank, R.D.; Birk, D.E.; Lee, S.-J.; Rowe, D.; Feng, J.Q.; Greenspan, D.S. Induced ablation of Bmp1 and Tll1 produces osteogenesis imperfecta in mice. Hum. Mol. Genet. 2014, 23, 3085-3101. [CrossRef] [PubMed]

187. Syx, D.; Guillemyn, B.; Symoens, S.; Sousa, A.B.; Medeira, A.; Whiteford, M.; Hermanns-Lê, T.; Coucke, P.; De Paepe, A.; Malfait, F. Defective Proteolytic Processing of Fibrillar Procollagens and Prodecorin Due to BiallelicBMP1Mutations Results in a Severe, Progressive Form of Osteogenesis Imperfecta. J. Bone Miner. Res. 2015, 30, 1445-1456. [CrossRef] [PubMed]

188. Grover, M.; Brunetti-Pierri, N.; Belmont, J.; Phan, K.; Tran, A.; Shypailo, R.J.; Ellis, K.J.; Lee, B.H. Assessment of bone mineral status in children with Marfan syndrome. Am. J. Med. Genet. Part A 2012, 158A, 2221-2224. [CrossRef] [PubMed]

189. Carter, N.; Duncan, E.; Wordsworth, P. Bone mineral density in adults with Marfan syndrome. Rheumatology 2000, 39, 307-309. [CrossRef]

190. Sakai, L.Y.; Keene, D.R.; Renard, M.; De Backer, J. FBN1: The disease-causing gene for Marfan syndrome and other genetic disorders. Gene 2016, 591, 279-291. [CrossRef]

191. Folkestad, L.; Groth, K.A.; Shanbhogue, V.; Hove, H.; Kyhl, K.; Østergaard, J.R.; Jørgensen, N.R.; Andersen, N.H.; Gravholt, C.H. Bone Geometry, Density, and Microarchitecture in the Distal Radius and Tibia in Adults With Marfan Syndrome Assessed by HR-pQCT. J. Bone Miner. Res. 2020, 1-10.

192. Trifirò, G.; Mora, S.; Marelli, S.; Luzi, L.; Pini, A. Increased fracture rate in children and adolescents with Marfan syndrome. Bone 2020, 135, 115333. [CrossRef]

193. Moura, B.; Tubach, F.; Sulpice, M.; Boileau, C.; Jondeau, G.; Muti, C.; Chevallier, B.; Ounnoughene, Y.; Le Parc, J.-M. Bone mineral density in Marfan syndrome. A large case-control study. Jt. Bone Spine 2006, 73, 733-735. [CrossRef]

194. Loeys, B.L.; Chen, J.; Neptune, E.R.; Judge, D.P.; Podowski, M.; Holm, T.; Meyers, J.; Leitch, C.C.; Katsanis, N.; Sharifi, N.; et al. A syndrome of altered cardiovascular, craniofacial, neurocognitive and skeletal development caused by mutations in TGFBR1 or TGFBR2. Nat. Genet. 2005, 37, 275-281. [CrossRef] [PubMed]

195. Kirmani, S.; Tebben, P.J.; Lteif, A.N.; Gordon, D.; Clarke, B.L.; Hefferan, T.E.; Yaszemski, M.J.; McGrann, P.S.; Lindor, N.M.; Ellison, J.W. Germline TGF-beta receptor mutations and skeletal fragility: A report on two patients with Loeys-Dietz syndrome. Am. J. Med. Genet. A 2010, 152A, 1016-1019. [CrossRef] [PubMed] 
196. Tan, E.W.; Offoha, R.U.; Oswald, G.L.; Skolasky, R.L.; Dewan, A.K.; Zhen, G.; Shapiro, J.R.; Dietz, H.C.; Cao, X.; Sponseller, P.D. Increased fracture risk and low bone mineral density in patients with loeys-dietz syndrome. Am. J. Med Genet. Part A 2013, 161, 1910-1914. [CrossRef] [PubMed]

197. Dewan, A.K.; Tomlinson, R.E.; Mitchell, S.; Goh, B.C.; Yung, R.M.; Kumar, S.; Tan, E.W.; Faugere, M.-C.; Ziegler, S.G.; Clemens, T.L.; et al. Dysregulated TGF- $\beta$ signaling alters bone microstructure in a mouse model of Loeys-Dietz syndrome. J. Orthop. Res. 2015, 33, 1447-1454. [CrossRef]

198. Janssens, K.; Dijke, P.T.; Ralston, S.H.; Bergmann, C.; Van Hul, W. Transforming Growth Factor-beta 1 Mutations in Camurati-Engelmann Disease Lead to Increased Signaling by Altering either Activation or Secretion of the Mutant Protein. J. Biol. Chem. 2002, 278, 7718-7724. [CrossRef]

199. Grafe, I.; Yang, T.; Alexander, S.; Homan, E.P.; Lietman, C.; Jiang, M.M.; Bertin, T.K.; Munivez, E.; Chen, Y.; Dawson, B.; et al. Excessive transforming growth factor- $\beta$ signaling is a common mechanism in osteogenesis imperfecta. Nat. Med. 2014, 20, 670-675. [CrossRef]

200. Ralston, S.H.; de Crombrugghe, B. Genetic regulation of bone mass and susceptibility to osteoporosis. Genes Dev. 2006, 20, 2492-2506. [CrossRef]

201. Balla, B.; Kósa, J.P.; Kiss, J.; Borsy, A.; Podani, J.; Takács, I.; Lazáry, A.; Nagy, Z.; Bácsi, K.; Speer, G.; et al. Different gene expression patterns in the bone tissue of aging postmenopausal osteoporotic and non-osteoporotic women. Calcif. Tissue Int. 2008, 82, 12-26. [CrossRef]

202. Langdahl, B.L.; Carstens, M.; Stenkjær, L.; Eriksen, E.F. Polymorphisms in the transforming growth factor beta 1 gene and osteoporosis. Bone 2003, 32, 297-310. [CrossRef]

203. Watanabe, Y.; Kinoshita, A.; Yamada, T.; Ohta, T.; Kishino, T.; Matsumoto, N.; Ishikawa, M.; Niikawa, N.; Yoshiura, K. A catalog of 106 single-nucleotide polymorphisms (SNPs) and 11 other types of variations in genes for transforming growth factor-beta1 (TGF-beta1) and its signaling pathway. J. Hum. Genet. 2002, 47, 478-483. [CrossRef]

204. Boyden, L.M.; Mao, J.; Belsky, J.; Mitzner, L.; Farhi, A.; Mitnick, M.A.; Wu, D.; Insogna, K.; Lifton, R.P. High Bone Density Due to a Mutation in LDL-Receptor-Related Protein 5. N. Engl. J. Med. 2002, 346, 1513-1521. [CrossRef] [PubMed]

205. Balemans, W.; Ebeling, M.; Patel, N.; Van Hul, E.; Olson, P.; Dioszegi, M.; Lacza, C.; Wuyts, W.; Ende, J.V.D.; Willems, P.; et al. Increased bone density in sclerosteosis is due to the deficiency of a novel secreted protein (SOST). Hum. Mol. Genet. 2001, 10, 537-543. [CrossRef] [PubMed]

206. Hartikka, H.; Mäkitie, O.; Männikkö, M.; Doria, A.S.; Daneman, A.; Cole, W.G.; Ala-Kokko, L.; Sochett, E.B. Heterozygous Mutations in the LDL Receptor-Related Protein 5 (LRP5) Gene Are Associated With Primary Osteoporosis in Children. J. Bone Miner. Res. 2005, 20, 783-789. [CrossRef] [PubMed]

207. Korvala, J.; Jüppner, H.; Mäkitie, O.; Sochett, E.; Schnabel, D.; Mora, S.; Bartels, C.F.; Warman, M.L.; Deraska, D.; Cole, W.G.; et al. Mutations in LRP5 cause primary osteoporosis without features of OI by reducing Wnt signaling activity. BMC Med. Genet. 2012, 13, 26. [CrossRef]

208. Manolagas, S.C. Wnt signaling and osteoporosis. Maturitas 2014, 78, 233-237. [CrossRef]

209. Zheng, H.F.; Tobias, J.H.; Duncan, E.; Evans, D.M.; Eriksson, J.; Paternoster, L.; Yerges-Armstrong, L.M.; Lehtimäki, T.; Bergström, U.; Kähönen, M.; et al. WNT16 influences bone mineral density, cortical bone thickness, bone strength, and osteoporotic fracture risk. PLoS Genet. 2012, 8, e1002745. [CrossRef]

210. Keupp, K.; Beleggia, F.; Kayserili, H.; Barnes, A.M.; Steiner, M.; Semler, O.; Fischer, B.; Yigit, G.; Janda, C.Y.; Becker, J.; et al. Mutations in WNT1 cause different forms of bone fragility. Am. J. Hum. Genet. 2013, 92, 565-574. [CrossRef]

211. Laine, C.M.; Joeng, K.S.; Campeau, P.M.; Kiviranta, R.; Tarkkonen, K.; Grover, M.; Lu, J.T.; Pekkinen, M.; Wessman, M.; Heino, T.J.; et al. WNT1 mutations in early-onset osteoporosis and osteogenesis imperfecta. N. Engl. J. Med. 2013, 368, 1809-1816. [CrossRef]

212. Luther, J.; Yorgan, T.A.; Rolvien, T.; Ulsamer, L.; Koehne, T.; Liao, N.; Keller, D.; Vollersen, N.; Teufel, S.; Neven, M.; et al. Wnt1 is an Lrp5-independent bone-anabolic Wnt ligand. Sci. Transl. Med. 2018, 10, eaau7137. [CrossRef]

213. Korvala, J.; Löija, M.; Mäkitie, O.; Sochett, E.; Jüppner, H.; Schnabel, D.; Mora, S.; Cole, W.G.; Ala-Kokko, L.; Männikkö, M. Rare variations in WNT3A and DKK1 may predispose carriers to primary osteoporosis. Eur. J. Med Genet. 2012, 55, 515-519. [CrossRef] 
214. Li, X.; Liu, D.; Li, J.; Yang, S.; Xu, J.; Yokota, H.; Zhang, P. Wnt3a involved in the mechanical loading on improvement of bone remodeling and angiogenesis in a postmenopausal osteoporosis mouse model. FASEB J. 2019, 33, 8913-8924. [CrossRef]

215. Tella, S.H.; Gallagher, J.C. Prevention and treatment of postmenopausal osteoporosis. J. Steroid Biochem. Mol. Biol. 2014, 142, 155-170. [CrossRef]

216. Russow, G.; Jahn, D.; Appelt, J.; Märdian, S.; Tsitsilonis, S.; Keller, J. Anabolic Therapies in Osteoporosis and Bone Regeneration. Int. J. Mol. Sci. 2018, 20, 83. [CrossRef] [PubMed]

217. Baron, R.; Gori, F. Targeting WNT signaling in the treatment of osteoporosis. Curr. Opin. Pharmacol. 2018, 40, 134-141. [CrossRef] [PubMed]

218. Bandeira, L.; Lewiecki, E.M.; Bilezikian, J.P. Romosozumab for the treatment of osteoporosis. Expert Opin. Biol. Ther. 2017, 17, 255-263. [CrossRef] [PubMed]

219. McClung, M.R.; Grauer, A.; Boonen, S.; Bolognese, M.A.; Brown, J.P.; Diez-Perez, A.; Langdahl, B.L.; Reginster, J.Y.; Zanchetta, J.R.; Wasserman, S.M.; et al. Romosozumab in postmenopausal women with low bone mineral density. N. Engl. J. Med. 2014, 370, 412-420. [CrossRef]

220. Li, X.; Ominsky, M.S.; Warmington, K.S.; Morony, S.; Gong, J.; Cao, J.; Gao, Y.; Shalhoub, V.; Tipton, B.; Haldankar, R.; et al. Sclerostin antibody treatment increases bone formation, bone mass, and bone strength in a rat model of postmenopausal osteoporosis. J. Bone Miner. Res. 2009, 24, 578-588. [CrossRef]

221. Fahiminiya, S.; Majewski, J.; Mort, J.; Moffatt, P.; Glorieux, F.H.; Rauch, F. Mutations in WNT1 are a cause of osteogenesis imperfecta. J. Med Genet. 2013, 50, 345-348. [CrossRef]

Publisher's Note: MDPI stays neutral with regard to jurisdictional claims in published maps and institutional affiliations.

(C) 2020 by the authors. Licensee MDPI, Basel, Switzerland. This article is an open access article distributed under the terms and conditions of the Creative Commons Attribution (CC BY) license (http://creativecommons.org/licenses/by/4.0/). 